\title{
Rebuild of the Bulletin of the International Seismological Centre (ISC)—part 2: 1980-2010
}

\author{
Dmitry A. Storchak ${ }^{1 *}$, James Harris ${ }^{1}$, Lonn Brown ${ }^{1,2}$, Kathrin Lieser ${ }^{1}$, Blessing Shumba ${ }^{1}$ \\ and Domenico Di Giacomo'
}

\begin{abstract}
The Bulletin of the International Seismological Centre (ISC) remains in demand for a wide range of geophysical studies. Users of the ISC Bulletin benefit from its long-term coverage, the most comprehensive set of measurements from the majority of permanent seismic stations and networks, and homogeneity of included parameters of earthquakes and other seismic events worldwide. Despite a reasonably conservative approach in preserving the operational procedures, changes are inevitable in order to achieve the best possible accuracy of published earthquake parameters. The last fundamental change in procedures has fully affected the data for years 2011 and beyond (Bondár and Storchak in Geophys J Int 186: 1220-1244, 2011). This is why it was decided to rebuild the earlier part (1964-2010) of the ISC Bulletin to achieve compatibility in earthquake hypocentres and magnitudes through its entire period. The first article on this project (Storchak et al. in Geosci Lett 4: 32, 2017) covered the period from 1964 to 1979, as it was publicly released. This article covers the remaining period from 1980 to 2010 with all seismic events re-processed and re-located in line with the modern ISC procedures, with 489,000 new events, 2600 new stations, 15.5 million new seismic arrivals, and more robust and reliable $m b$ and MS magnitude evaluations. We give statistics of departures in epicentre location and depth between the original and rebuilt ISC hypocentres. We also provide a summary for the entire rebuilt period (1964-2010). We give a brief account of events deleted from and added to the Bulletin, based on additional reports from permanent and temporary seismic deployments. We explain that newly re-computed (rebuilt) $m b$ is on average larger that the original $m b$ by 0.05 unit of magnitude. The rebuilt MS is only 0.01 unit larger that its predecessor. We announce that the entire reviewed part of the ISC Bulletin (1964-2017) is now based on the same velocity model, $a k 135$, and the same earthquake location and magnitude computation procedures. Finally, we provide advice on how to obtain the original ISC Bulletin data, where necessary.
\end{abstract}

Keywords: ISC, Earthquake, Bulletin, Rebuild, Global, Re-location, Magnitude, Homogeneity, Long-term, Seismicity

\section{Introduction}

The most important long-term mission of the International Seismological Centre (ISC) has always been the production of the global definitive earthquake Bulletin (International Seismological Centre 2020a) which to this day remains in high demand for a wide range of geophysical studies. Selected references to hundreds of scientific articles that acknowledge use of ISC data can be found at

\footnotetext{
${ }^{*}$ Correspondence: dmitry@isc.ac.uk

${ }^{1}$ International Seismological Centre, Pipers Lane, Thatcham RG19 4NS, Berkshire, UK

Full list of author information is available at the end of the article
}

the end of each annual ISC Director's Report available at https://www.isc.ac.uk/docs/dirreport/.

Users of the ISC Bulletin benefit from its long-term coverage, the most comprehensive set of measurements from the majority of permanent seismic stations and networks, and homogeneity of included parameters of earthquakes and other seismic events worldwide.

As current data (hypocentre solutions, magnitudes, focal mechanisms, seismic phase arrival times, amplitudes and periods) from reporting agencies arrived (Willemann and Storchak 2001), they were integrated, re-assessed, reviewed and published to keep the Bulletin

\section{Springer Open}

(c) The Author(s) 2020. This article is licensed under a Creative Commons Attribution 4.0 International License, which permits use, sharing, adaptation, distribution and reproduction in any medium or format, as long as you give appropriate credit to the original author(s) and the source, provide a link to the Creative Commons licence, and indicate if changes were made. The images or other third party material in this article are included in the article's Creative Commons licence, unless indicated otherwise in a credit line to the material. If material is not included in the article's Creative Commons licence and your intended use is not permitted by statutory regulation or exceeds the permitted use, you will need to obtain permission directly from the copyright holder. To view a copy of this licence, visit http://creativeco mmons.org/licenses/by/4.0/. 
approximately 24 months behind real time. With the exception of a few cases, representation of earthquakes and other seismic events in the Bulletin did not change, once published.

To maintain homogeneity of data over the tens of years, the ISC followed a reasonably conservative approach (Adams et al. 1982). Nevertheless, the advances in global earthquake science have pushed their way into the ISC procedures that have changed most dramatically during processing of data years 2009-2011. With data year 2011, the current earthquake location and magnitude determination methodology (Bondár and Storchak 2011) finally settled, for however many data years to come. This methodology uses all reported seismic phases with a valid ak135 prediction and takes into account the correlated travel-time prediction error structure, which produces more reliable uncertainty estimates and reduces location bias for geometrically unbalanced networks. The need to re-compute the earlier part of the Bulletin (1964-2010) using the same current procedures was identified and has become a core task of the project of Rebuild of the ISC Bulletin.

\section{Procedures}

The first article on this project (Storchak et al. 2017) covered the results of the rebuild of the data period from 1964 to 1979 , which was released to users in early 2018. That article described the history of operational changes in the production of the ISC Bulletin and details of procedures used during the Rebuild project, which included:

- Removal of poorly constrained events;

- Correcting seismic phase names in line with Storchak et al. $(2003,2011,2013)$ and time stamp errors;

- Adding previously unavailable bulletin data;

- Computation of ISC hypocentres and magnitudes where appropriate, using ak135 velocity model and the location algorithm by Bondár and Storchak (2011);

- Manual review of parameters of ISC solutions with either considerable departures in epicentre/depth from the old ISC solution or large travel-time residuals at individual reporting stations;

- Final overall checks.

These procedures largely remained the same throughout the Rebuild project; therefore there is no need to cover them again in this article. Just one clarification we would make here is that the ISC hypocentre solutions were always based on station observations reported to the ISC by various agencies and not taken from waveforms at the ISC. The Rebuild project has not changed anything in this respect.
As to the general procedures that ISC uses, we would like to refer to the Appendix in any January-June issue of the Summary of the ISC Bulletin that contains a detailed explanation of the subject (International Seismological Centre 2020b). We shall now move to results for the data period from 1980 to 2010.

\section{Summary of results for the $\mathbf{1 9 8 0 - 2 0 1 0}$ period}

The ISC Bulletin contains information on seismic events, mostly earthquakes, reported by a large number of agencies around the world that follow their own policies and procedures. Smaller events, usually reported by single agencies, form part of the ISC Bulletin, but they are not reviewed by the ISC analysts and ISC hypocentre solutions are not attempted. For all other events, where solutions or station information is usually available from several agencies, we review the grouping of available information and, where certain criteria are met, we attempt to compute the ISC hypocentre and magnitudes.

In the course of the Rebuild project, we removed 76,938 events featured in the original ISC Bulletin (Fig. 1). These events generally fall into the following categories, listed in the order of frequency of occurrence:

- Events supported only by data from hydro-acoustic networks (more detailed explanation later in the article): account for approximately $64 \%$ of the total number of deleted events; shown in Fig. 1 as a cloud of epicentres in the Pacific and Atlantic Ocean regions;

- Poorly constrained events: usually reported by a single agency, where events are well outside the network with unacceptably small station azimuthal coverage and no stations at close distances;

- Events removed by the original reporter: in some instances, following our request for additional data we received the entire network bulletins that contained much more detailed and reviewed information on events of the past, but, due to retrospective analysis, changes in procedures or the area of responsibility, were missing certain events reported in the past; an example is the network in New Zealand, where 1200 events were either removed or relocated with a substantial departure in epicentre position or depth;

- Events with 1 min (hour, day, month or even a year) errors in origin time; suspicious almost identical pairs of events were identified in the original Bulletin; most of these events occurred during the period of analog instrument recordings where readings were manually taken from seismograms, at times erroneously; for example, there were two suspiciously similar events in the original ISC Bulletin: a magnitude $M L 2.6$ event was reported by KOERI observatory in Turkey (ISK) 


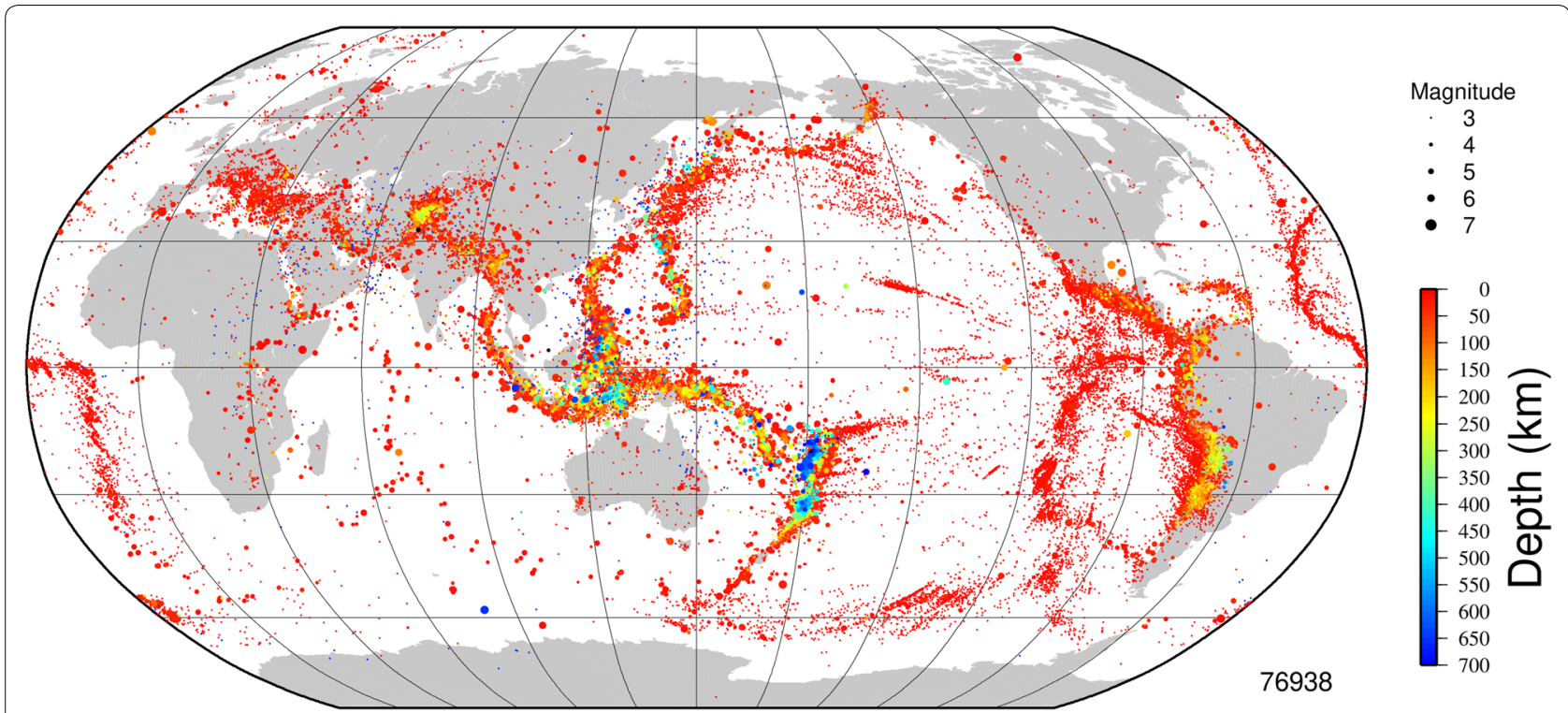

Fig. 1 A map of 76,938 poorly constrained or phantom seismic events (1980-2010) removed from the ISC Bulletin during the Rebuild project

directly to the ISC, approximately 2 years after event occurrence, with the origin time $11 \mathrm{~h} 10 \mathrm{~min} 55 \mathrm{~s}$ on February 20, 1992; at the same time, a very similar event with no magnitude estimate was reported to ISC by NEIC/USGS with the origin time $11 \mathrm{~h} 10 \mathrm{~min}$ 55s on March 20, 1992 and referenced to KOERI; the PES arrival times at all four reporting stations (IZI, DST, YLV and KCT) in the two events were identical to one-tenth of a second; this discrepancy was caused by an unfortunate mistake in either the preliminary fast report by KOERI to NEIC or by the interpretation of this report at NEIC; this mistake, somewhat typical for the time of analogue instruments, has now been corrected and the event in March has been deleted.

- So-called "split" events, usually caused by one of the agencies reporting a severely mis-located hypocentre solution that, in turn led to the formation of two separate events in the original ISC Bulletin, where in fact, there was just one physical event; such instances have been identified and rectified.

At the same time, we added a large number of additional reports based on both permanent and temporary seismic deployments. Figure 2 demonstrates a list of these contributions by 90 agencies with the timeline showing the period that each individual contribution covered. The Appendix below lists these agencies with explanations on the nature of each additional contribution and references to relevant scientific publications. As a result of the integration of these reports into the ISC
Bulletin, 489,000 new events have been added (Fig. 3). The majority of them are small events (such as those in Eastern Russia reported by MSUGS, based on the data of the local agencies), although these additional reports also contributed useful additional station measurements of already known moderate to large events.

With these additional reports, the Bulletin was enriched with $\sim 15$ million arrival times and amplitude/ period readings from $\sim 2600$ new stations, not present in the original Bulletin. These stations belonged to both permanent and temporary deployments. They helped to improve overall station coverage and thus source location accuracy in the Rebuilt bulletin. They also created alternative source-to-station paths useful in tomographic studies. Figure 4 shows the map of these stations. Some groups of stations reveal temporary station deployments such as those in Europe, Central and Eastern Africa, Tibet and the South Pacific. The map also shows additional stations of regional networks in Europe, Russia and the USA that did not report to the ISC directly.

All ISC hypocentre solutions have been recomputed using the current location procedures and $a k 135$ velocity model. In some instances, where the data did not warrant an ISC solution, the old ISC solutions were dropped and a local network's hypocentre was re-assigned as primary hypocentre. Figure 5 shows analysis of departures in ISC epicentre and depth between corresponding matching events in the original and rebuilt ISC Bulletins. It appears that in approximately $80 \%$ of cases, both epicentre and depth departures are within $20 \mathrm{~km}$ and in approximately $95 \%$ of cases the departures are within $40 \mathrm{~km}$. 


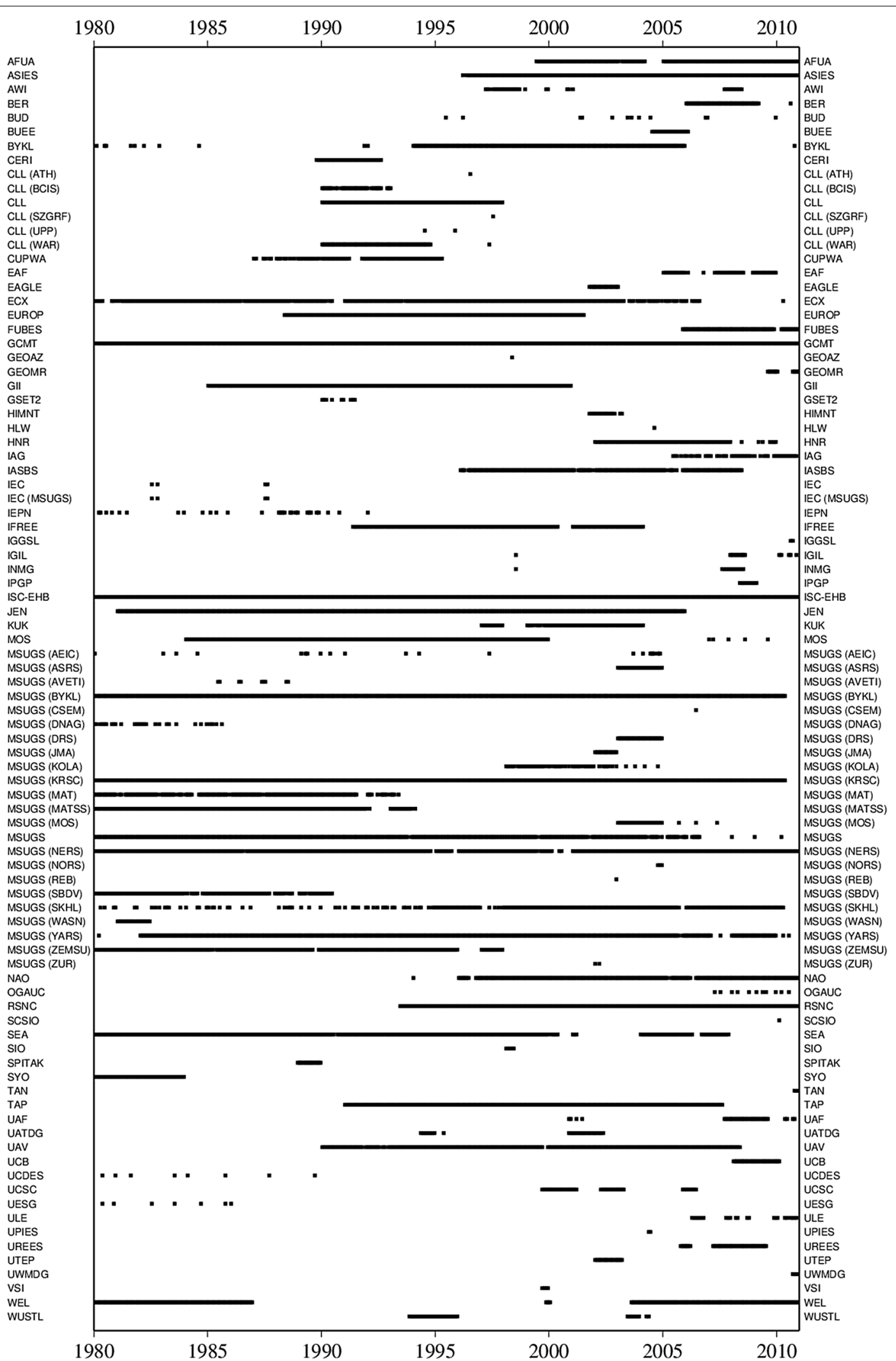

Fig. 2 Timeline of additional bulletin datasets introduced into the ISC Bulletin during the Rebuild project; 90 agency codes are listed in the Appendix; on each line, the first agency code belongs to the reporter of the data and, if different, the second (in brackets) - to its original author 


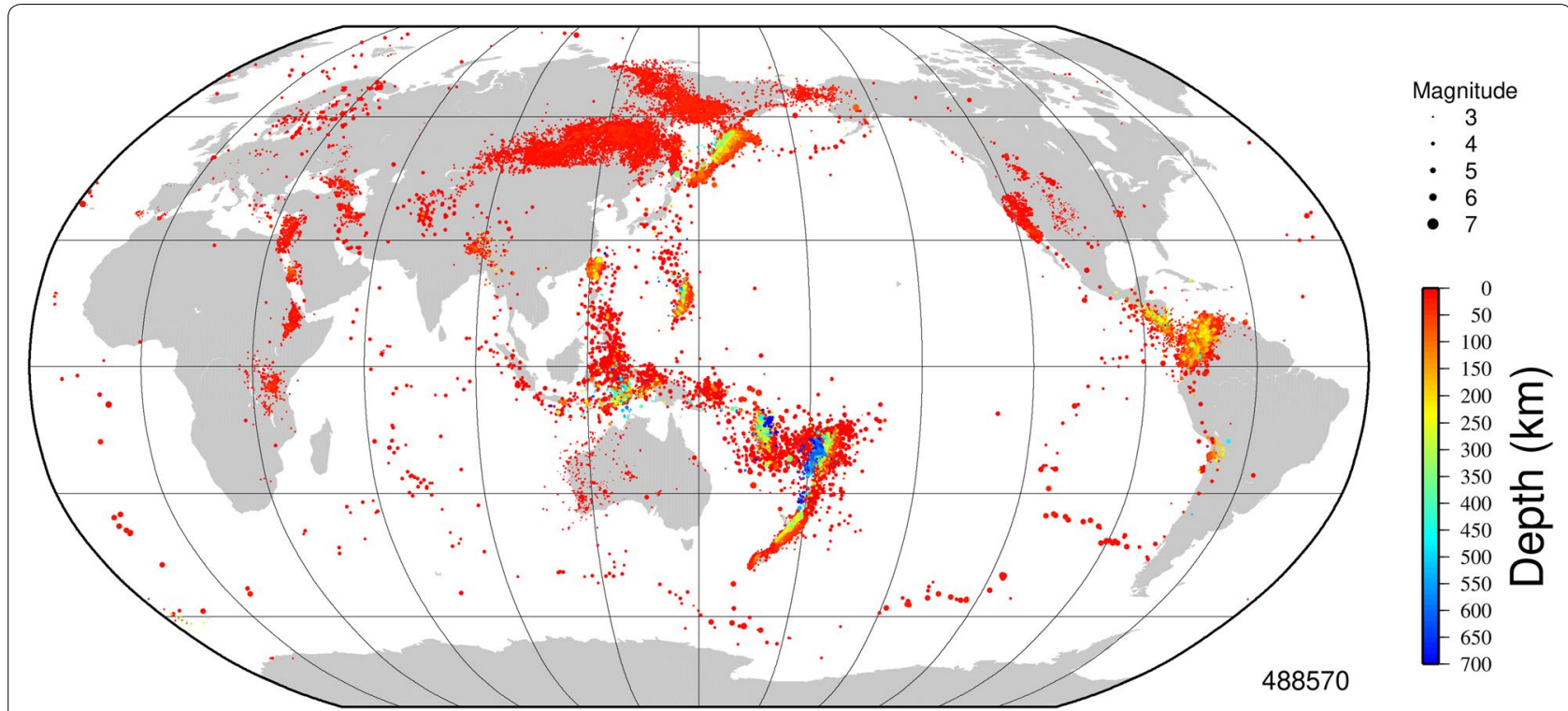

Fig. 3 A map of 488,570 earthquakes and other seismic events (1980-2010) added to the ISC Bulletin during the Rebuild project

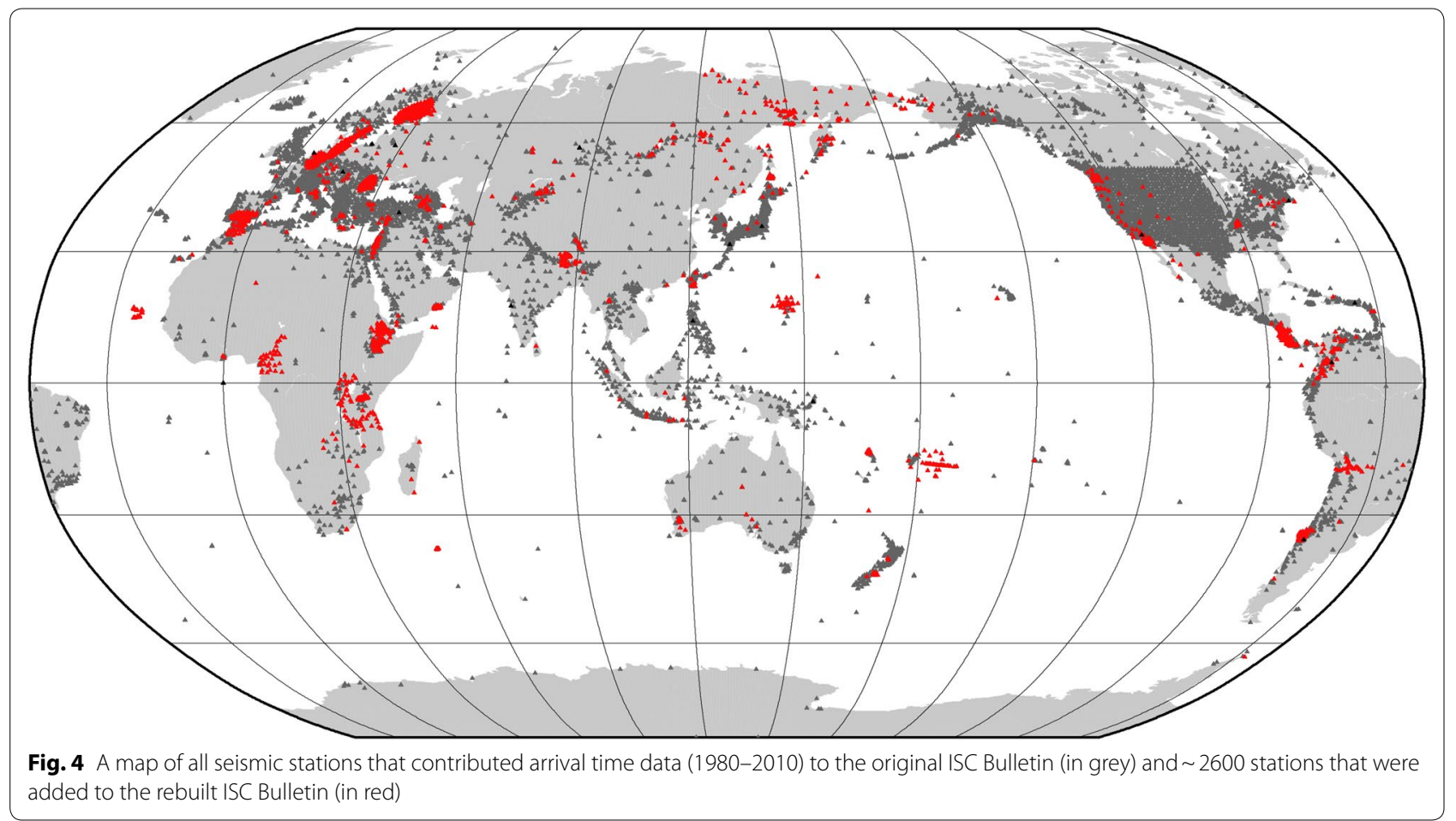

Only 2698 events ( $\sim 0.6 \%)$ show an epicentre difference in excess of $120 \mathrm{~km}$. Out of those, just 10 events had an epicentre difference in excess of $1000 \mathrm{~km}$.

The most extreme case was an earthquake that was originally believed to have occurred on July 9, 1983 in North Pacific Ocean with ISC $m b 5.5$, based on the amplitude/period pairs from 15 stations. This event was not reported by an agency but built at the ISC, based on the un-associated station arrival time reports sent separately by several agencies-a so-called "search" event. Its ISC hypocentre solution in the original Bulletin was based on the readings of 47 stations at recorded distances 


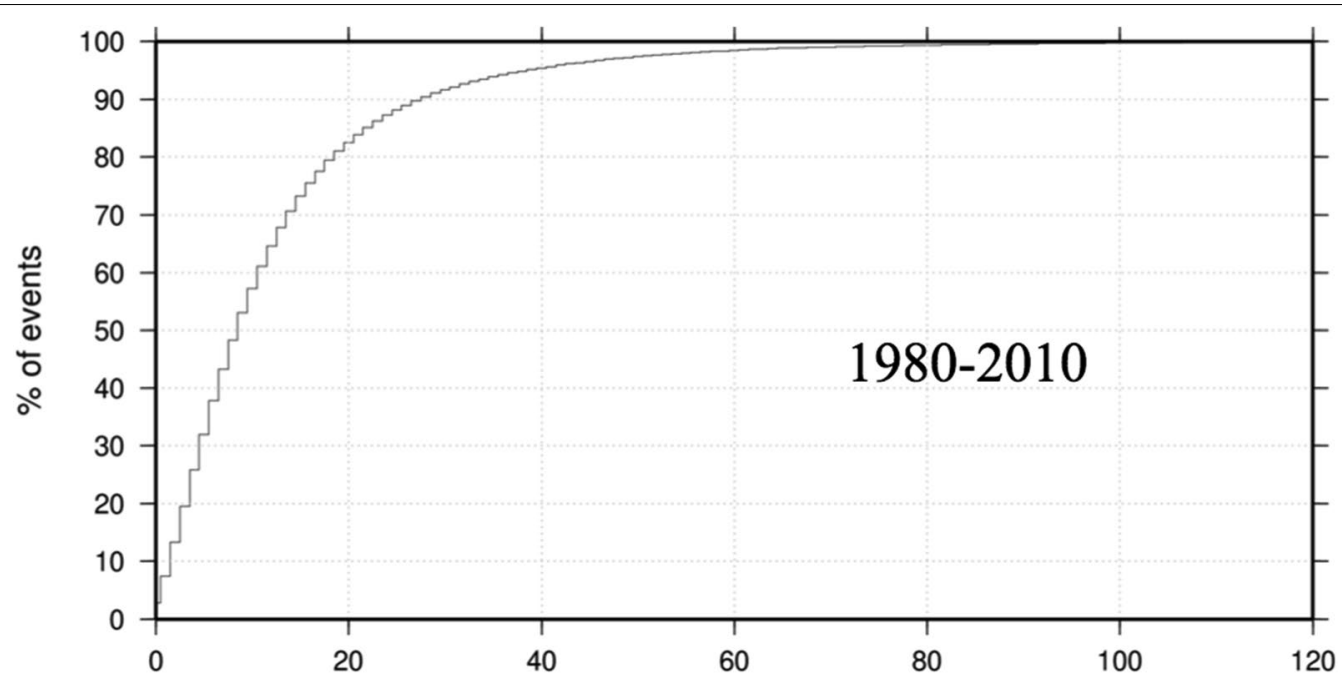

Distance between Original and Rebuilt ISC Bulletin, km

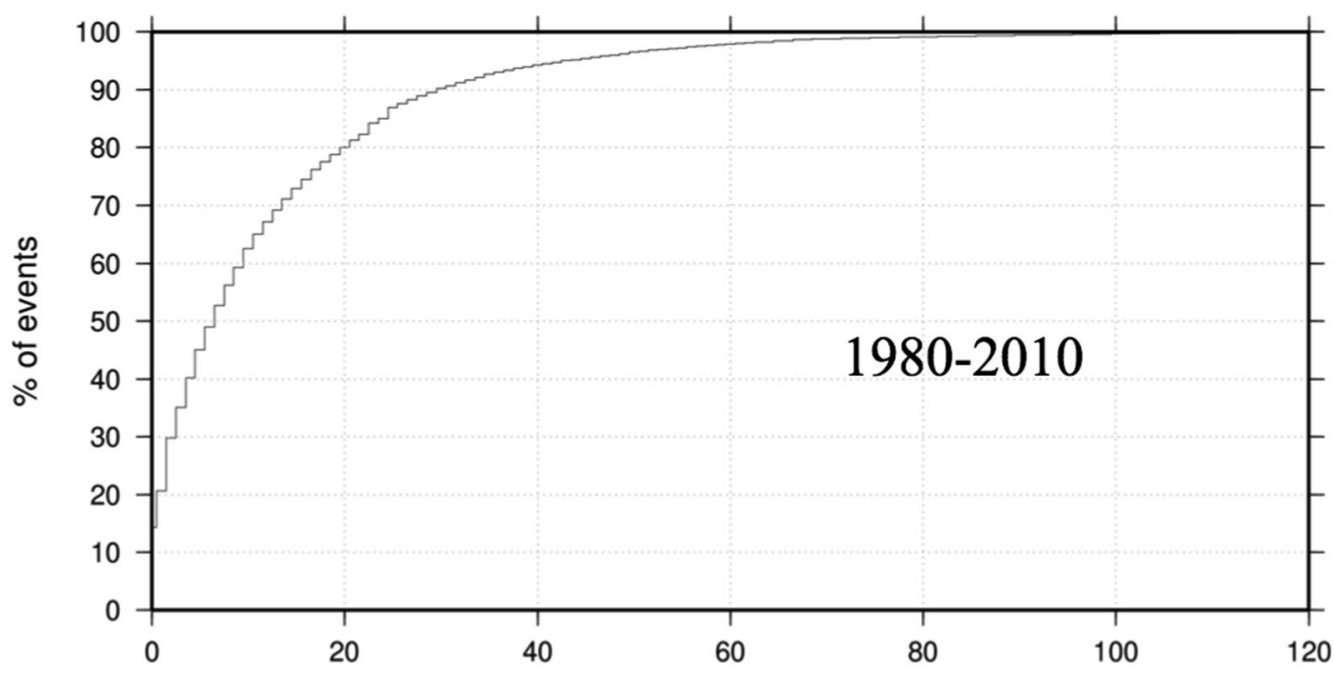

Depth difference between Original and Rebuilt ISC Bulletin, km

Fig. 5 Cumulative statistics of departures in location and depth of origin between matching events in the original and rebuilt ISC Bulletins (1980-2010)

in the range of $27-101^{\circ}$ which had an azimuthal coverage of $143^{\circ}$. The stations included MTN (Australia), TRT (Indonesia), BJI (China) and 44 European stations that were interpreted as direct $\mathrm{P}$-arrivals. In fact, the $S-P$ time difference reported at MTN was inconsistent with the station's epicentral distance and thus indicated a possible mis-association of this reading to this event, but it was sadly overlooked at the time.

As a result of the current analyst's review during the Rebuild project, we found in the ISC database a set of other reported readings that fitted along with all original station readings in Europe (if interpreted as PKP arrivals) and BJI. These readings included $P$ and $S$ pairs from NOU and KOU (New Caledonia), and PVC (Vanuatu); direct $P$-arrivals at BRS, CTA and CTAO (Australia), KRP, MNG, MSZ (New Zealand) and SPA (South Pole, Antarctica). The originally associated readings of MTN and TRT have been disassociated. The whole new event was found to occur Southeast of the Loyalty Islands (a staggering move of $6197 \mathrm{~km}$ ) with 56 associated stations in the distance range of $3.9-156.2^{\circ}$ and the station azimuthal coverage of $192^{\circ}$ (Fig. 6). Sadly, there was only one amplitude/period pair at SPA that fell into a legitimate distance range for $m b$. All amplitude/period pairs from 


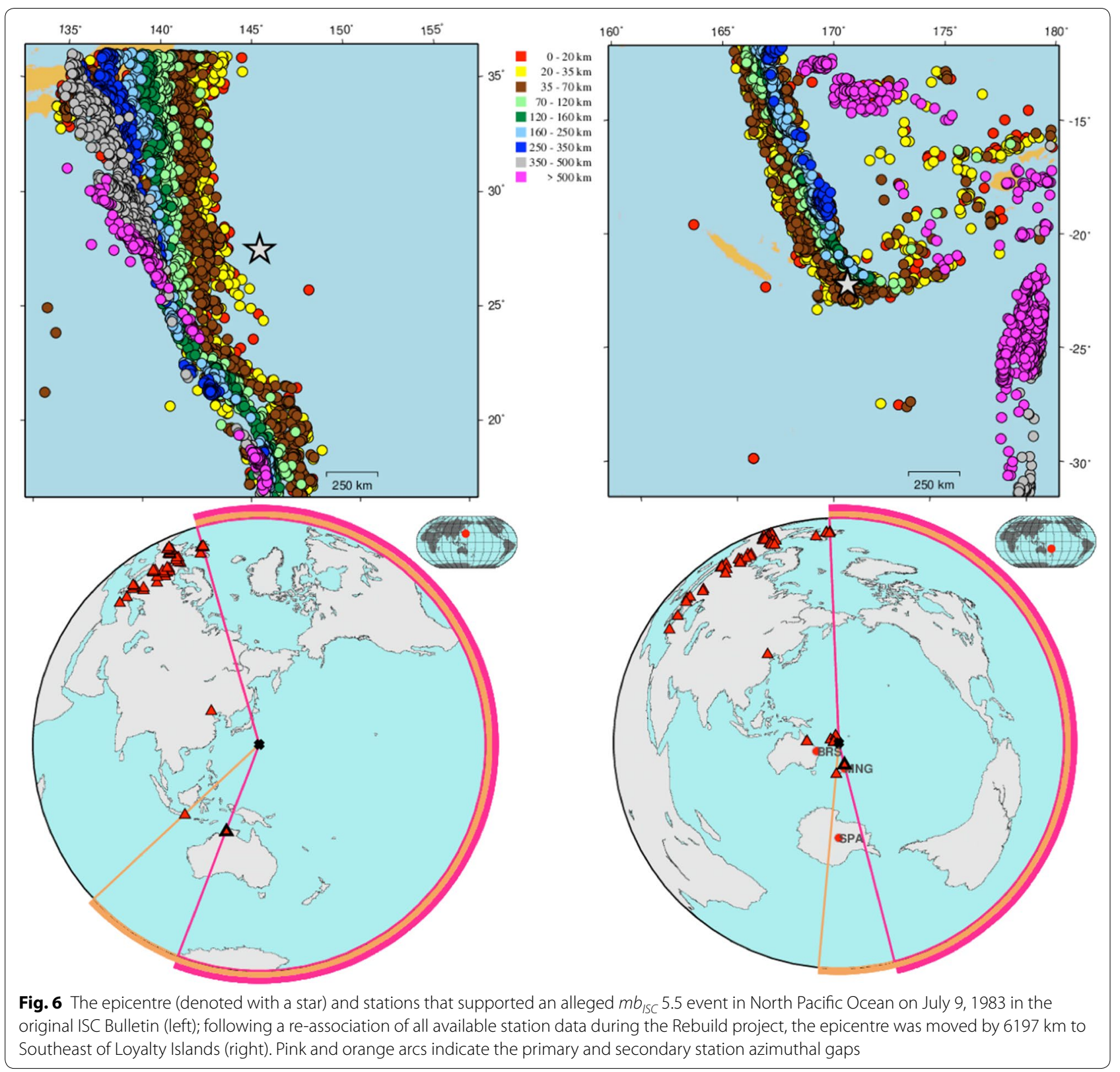

Europe, now treated as PKP amplitudes, were out of the range. Thus, no new ISC $m b$ was included in the Rebuild Bulletin for this event and the original $m b 5.5$ has been removed. All station codes above are part of the International Seismograph Station Registry (International Seismological Centre 2020c).

Only 3260 events $(\sim 0.7 \%)$ show a depth difference in excess of $120 \mathrm{~km}$. The extreme cases of depth difference were usually attributed to subduction zones, such as Kermadec, Fiji-Tonga, Solomon and Vanuatu where (due to lack of depth constraint) different default depths have been selected in the original and the rebuilt ISC Bulletins.
The current system of default depths, used in the rebuilt Bulletin is more consistent because it is based on general statistics of well-located events in each geographical area/cell. If such statistics are insufficient in some regions of low seismicity, then general defaults of 10 or $35 \mathrm{~km}$ are used. For details, please see the Appendix in each January-June issue of the Summary of the Bulletin (International Seismological Centre 2020b).

All ISC magnitudes were re-computed in line with new more robust procedures that require at least three station amplitude/period measurements and use alphatrimmed median to compute a network magnitude and 
uncertainty. This means that the network magnitude is determined as the median of station magnitudes after discarding the lower and upper 20 percentiles, and its uncertainty is given by the SMAD around the median (Bondár and Storchak 2011). Alpha-trimming does not change the median, but it does affect the magnitude uncertainty by avoiding the outliers.

Notably, many events lost their original $m b$ or $M S$ estimates where amplitude/period pairs were available at less than three stations. Figure 7 shows the timeline of this reduction. With a much larger overall number of stations closer to the end of the period, it was inevitable that a lot smaller proportion of events per year lost their $m b$ magnitudes in recent years as compared to the 1980s and mid-1990s. With MS magnitudes this effect is not obvious, partly because of the large original number of events in recent years, where just one or two automatic surface wave readings were provided by PIDC (during the period 1995-2000) and then by IDC/CTBTO (from 2000-02-26 to present) driven by their important requirement to provide data for $m b / M S$ event type discrimination. Original versus rebuilt numbers of both $m b$ and $M S$ are very similar during 2009 and 2010. This is because current magnitude computation procedures have already been used in the original ISC Bulletin for these 2 years. We included the $2009-2010$ period in Rebuild as a precaution, because
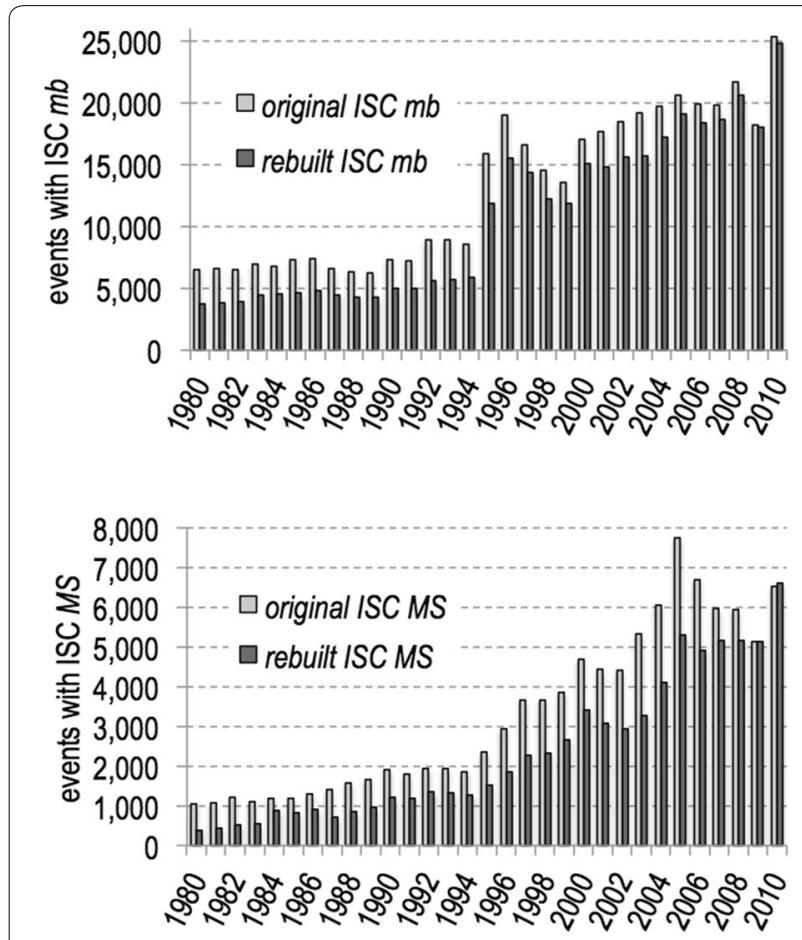

Fig. 7 Annual distribution of the original and rebuilt ISC $m b$ (top) and MS (bottom) magnitudes during this data period certain teething problems have been identified and fixed, and we wanted to re-run the updated procedures systematically over these 2 years.

Figure 8 shows the change in the global magnitude frequency distributions for $m b$ and $M S$. These graphs also show a considerable drop in the number of $m b$ and $M S$ estimates for moderate-to-small events where less amplitude data are available. By design, only poorly constrained estimates were lost in order to make the ISC magnitudes generally more reliable. We avoid making any conclusions on the apparent drop in completeness of the overall catalogue. Completeness of the ISC Bulletin is highly variable throughout the world and global graphs can often be misleading if used for this purpose. Regional study of completeness is an important topic in its own right and is therefore outside the scope of this article.

Having finished with the analysis of the rebuilt ISC Bulletin in two major time periods, released to users separately (1964-1979 and 1980-2010), we now move to an overall analysis of changes in the Rebuilt ISC Bulletin for the entire rebuilt period (1964-2010).

\section{Analysis of the entire rebuilt period (1964-2010)}

The ISC Bulletin is a collection of information about unique seismic events, mostly earthquakes. Events come as reviewed (generally larger) or not-reviewed (generally smaller), depending on whether the event parameters and corresponding station recording

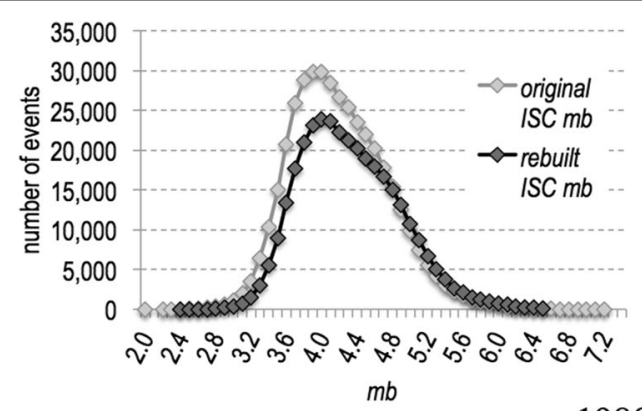

$1980-2010$

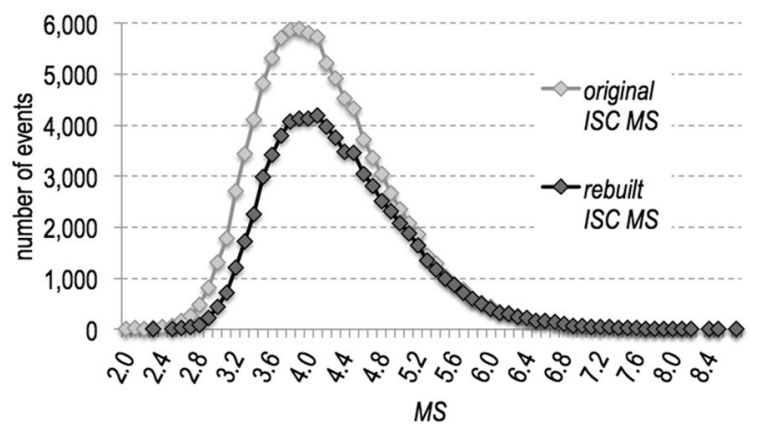

Fig. 8 ISC $m b$ (top) and MS (bottom) magnitude frequency distributions of the original and rebuilt ISC Bulletins (1980-2010) 


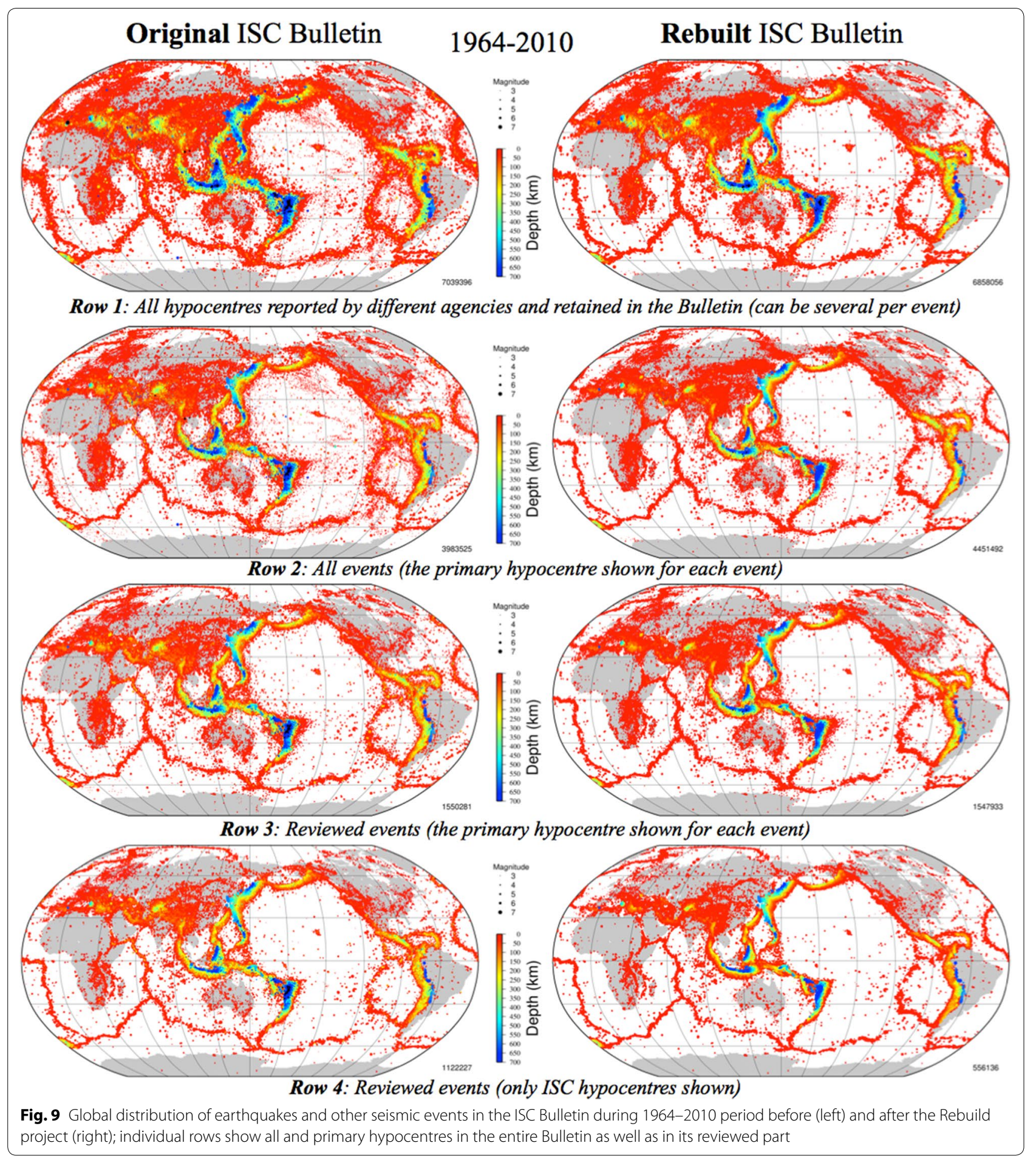

information have been manually assessed by ISC analysts. Each event is characterised by one or a few hypocentre solutions, one of which is set as the primary (prime). If an ISC hypocentre is available, then it is most likely to be the prime solution and the event is always considered as Reviewed. Each event is accompanied by a number of magnitudes, fault plane solutions, felt reports, comments and seismic phase arrival time information at a variety of seismic stations, supplied by different reporters, including the ISC itself. 


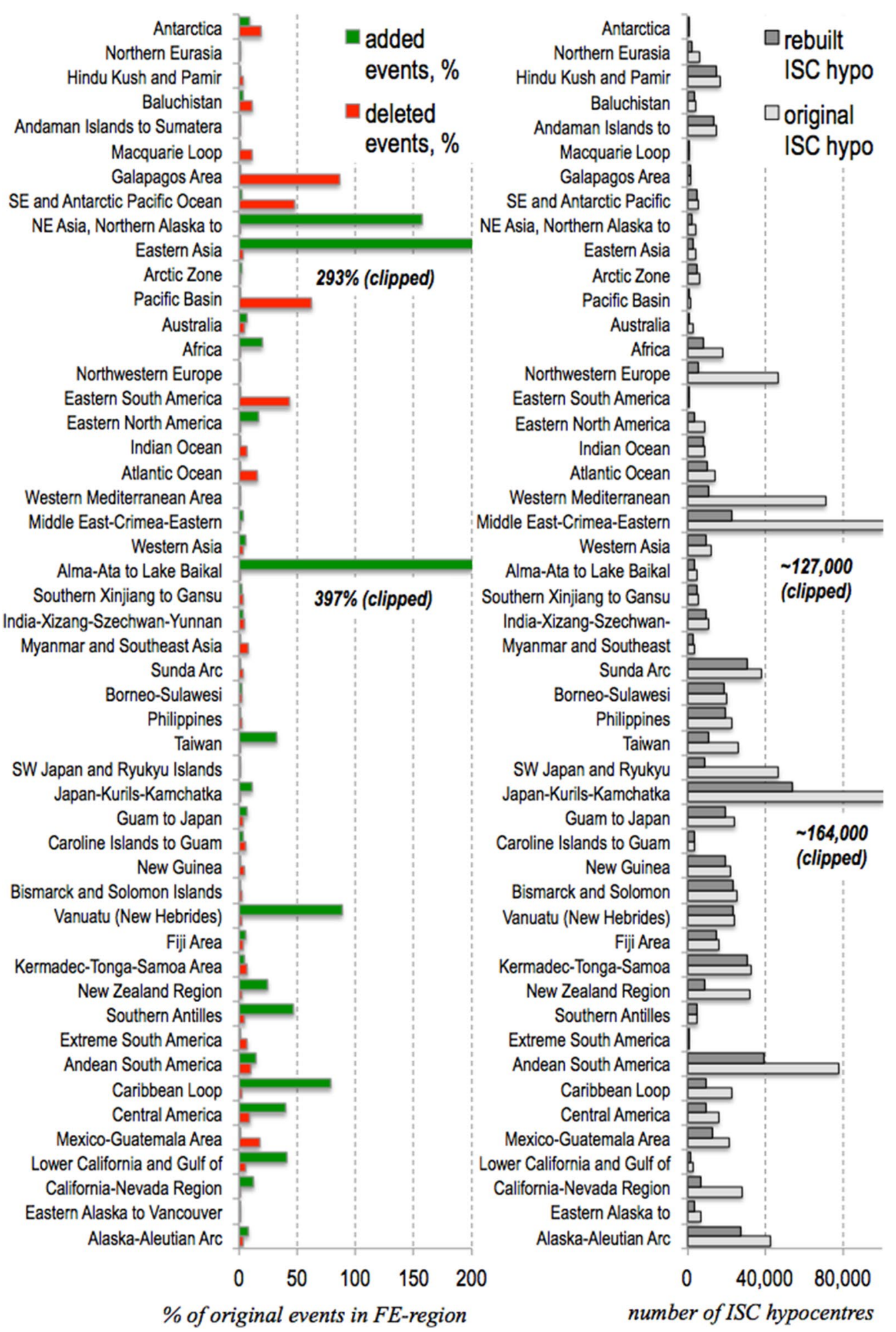

Fig. 10 Regional distribution (FE-Flinn and Engdahl, 1974; Young et al., 1996) of seismic events deleted and added to the ISC Bulletin (left) and the FE-distribution of the ISC hypocentres in the original and rebuilt ISC Bulletins (right) 


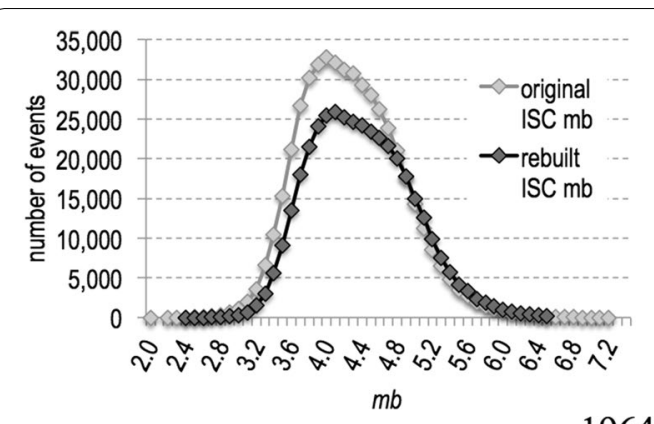

$1964-2010$

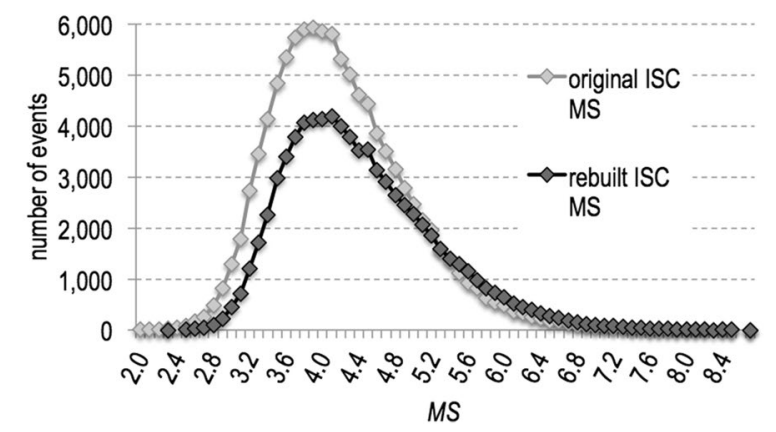

Fig. 11 ISC mb (top) and MS (bottom) magnitude frequency distribution in the original ISC and rebuilt ISC Bulletins (1964-2010)

As a result of the Rebuild project, the ISC Bulletin within the 1964-2010 period has experienced a large transformation. In particular, a large number of events and hypocentre solutions have been deleted or added. Figure 9 shows this transformation in before/after style, demonstrating:

- Removal of poorly constrained and, at times, phantom hypocentres (panel row 1) or entire events (panel rows 2 and 3 ) reported to the ISC (for example, the former artificial arc crossing Africa that consisted of single low aperture array solutions (LAO) or events in the Pacific and Atlantic constrained solely by hydro-acoustic stations);

- Removal of many ISC hypocentre solutions (but not events) where hypocentre solutions of local agencies were considered to be sufficient to serve as primary and ISC had no further station reports in addition to the station reports of that local agency (for example, for small events in Japan and South Africa, panel row 4);

- Addition of many previously unreported events, mostly of small-to-moderate magnitudes (for example, in Russian Far East, panel row 2) based on additional bulletin contributions collected during the project, such as those shown in Fig. 2.
Figure 10 shows regional details of seismic events (1964-2010) deleted from and added to the rebuilt ISC Bulletin per Flinn-Engdahl (FE) regions (Flinn et al. 1974). Only $\sim 2.5 \%$ of events have been deleted, usually due to being poorly constrained. The large fraction of them were those reported solely by hydro-acoustic networks in the Pacific and Atlantic oceans (FE-regions: Galapagos Area, SE and Antarctic Pacific Ocean, Eastern South America, Atlantic Ocean). Although many of these events were real, their location was poorly constrained. The main mission of the ISC, to present the most accurate account of world seismicity, dictated these events be removed. The number of events has increased by $\sim 14.2 \%$ with the addition of many previously described reports from temporary and permanent networks. The most prominent was the addition of a large number of small events in Siberia and Far East (Mackey et al. 2010).

Figure 10 also shows the change in the overall number of ISC hypocentres in each FE-region. Before data year 1999, the ISC aimed to compute its hypocentre for each event in the Bulletin. This practice has now changed to give prominence to local network hypocentres, where additional station data (if any) available to ISC do not present a reasonable chance of location improvement. This is why we deleted many ISC hypocentres for small events in Europe, Mediterranean, Japan and Chile. We obviously kept these events in the Bulletin and assigned the status of prime solution to hypocentres reported by established local agencies.

Figure 11 shows the magnitude frequency distribution plots for ISC $m b$ and MS during the 1964-2010 period. As explained before, many unreliable ISC $m b$ estimates have been removed. The $M S$ curve experienced a greater transformation for both large and small magnitudes because, originally, no ISC $M S$ magnitudes were available before 1978 and, on the other hand, there were many $M S$ estimates in the past, based on just one or two station measurements.

Because the ISC magnitudes have essentially been recomputed, it is important to state the overall difference between the original (old) and rebuilt (new) magnitudes. Figure 12 shows the density-distribution plot for ISC $m b$ for those events that had a magnitude in both the original and rebuilt Bulletins. During the period 1964-2010, the mean difference between the old and new $m b$ is $-0.05 \pm 0.11$, i.e. on average, the rebuilt $m b$ is 0.05 units of magnitude larger than the original $m b$. There can be many contributing factors to this small change. One of them is the change in the influence of large outliers (sometimes in excess of \pm 1.0 magnitude unit with respect to the mean): in the past, the ISC $m b$ was calculated as a mean value of all station magnitudes, whilst 

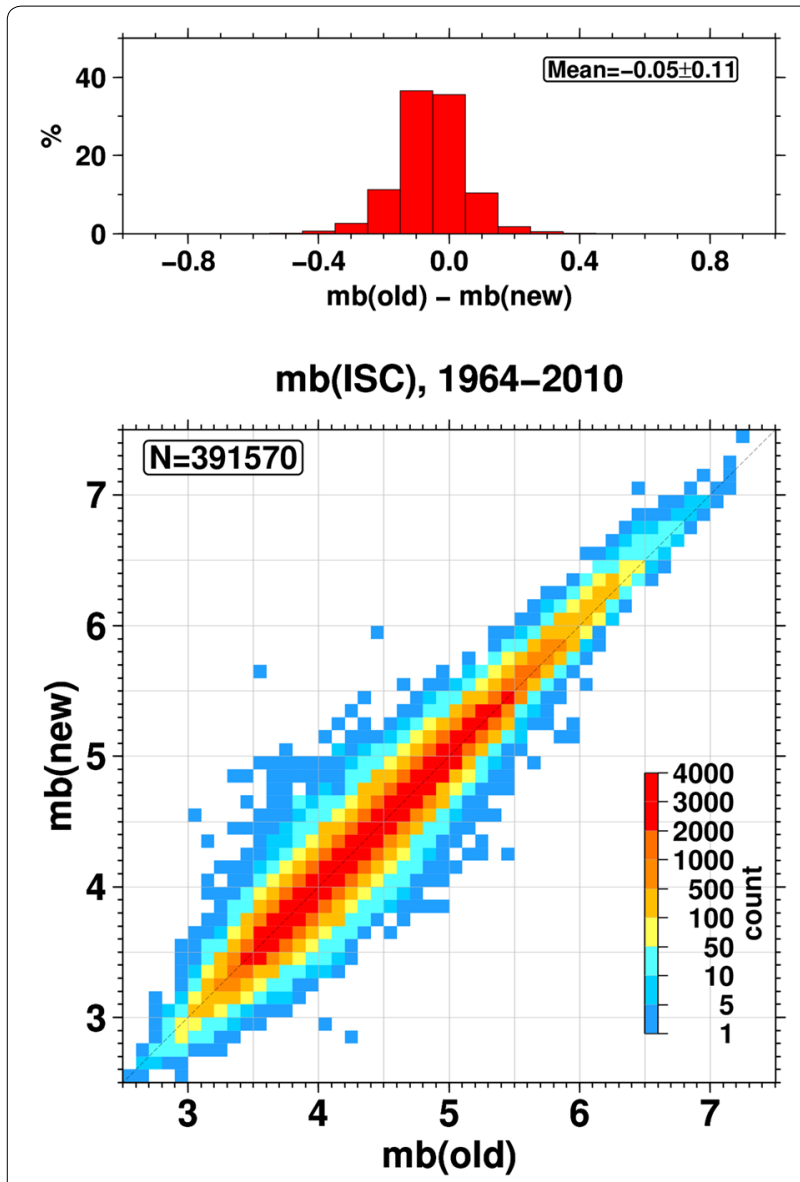

Fig. 12 Comparative analysis of ISC mb (1964-2010) for matching 391,570 events in the original and rebuilt ISC Bulletins

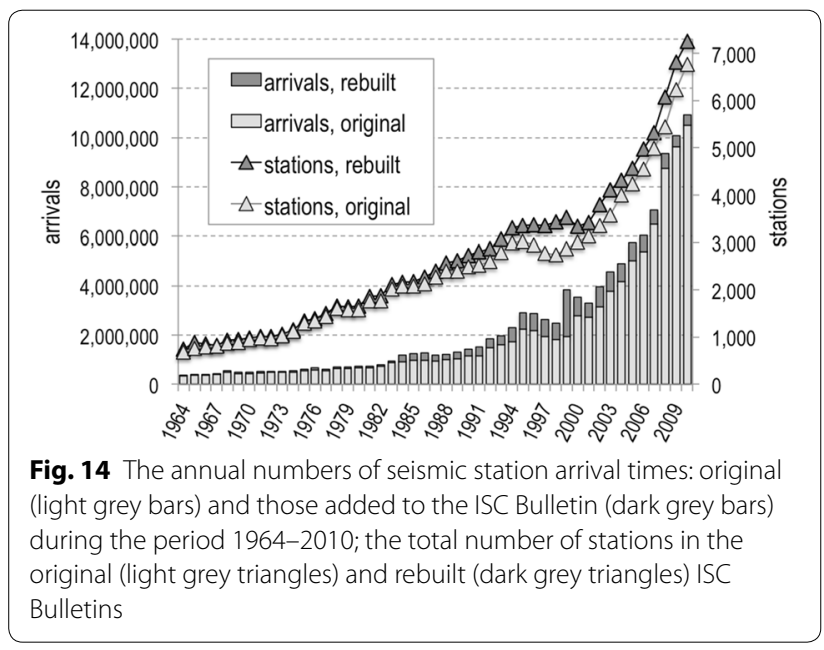

now it is based on the median value. Figure 13 shows similar information for ISC MS for the shorter period from 1978 to 2010. This is because the IASPEI practice

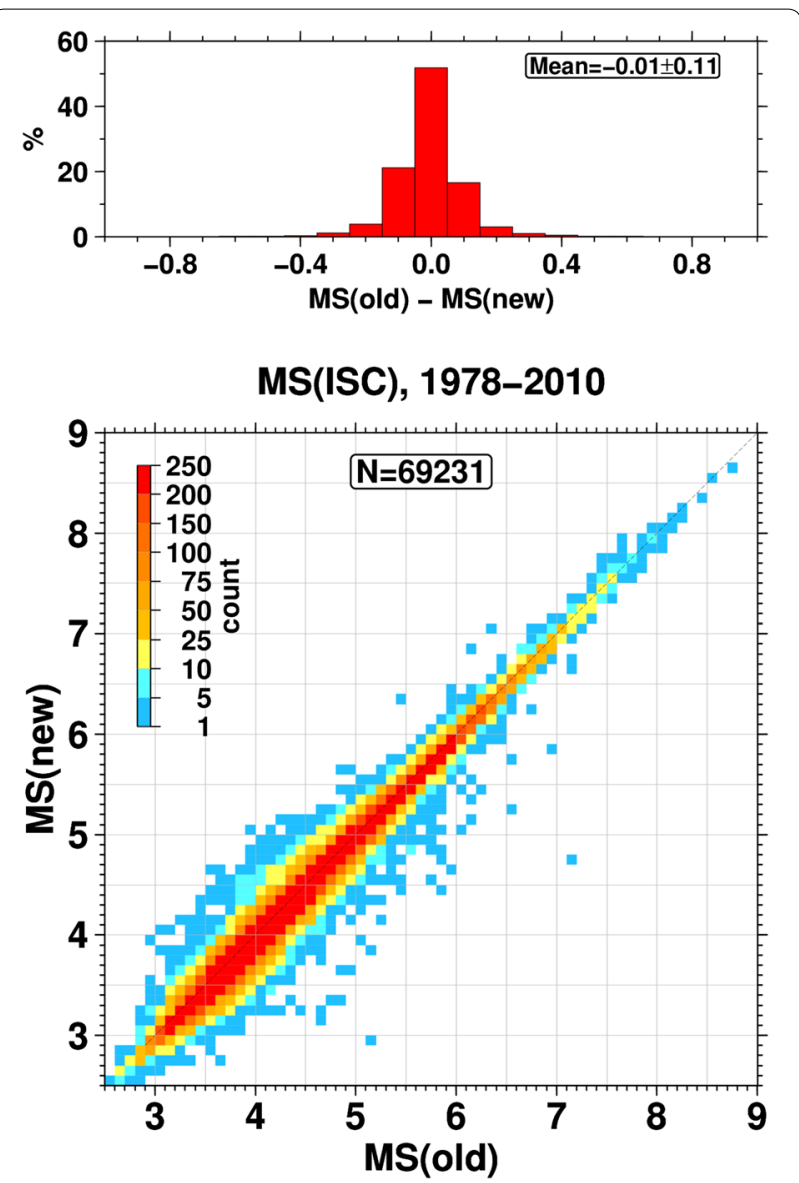

Fig. 13 Comparative analysis of ISC MS (1978-2010) for matching 69,231 events in the original and rebuilt ISC Bulletins

of MS computation, so-called "Prague formula" (Vaněk et al. 1962) has been introduced at the ISC only from data year 1978. In fact, the rebuilt Bulletin now contains many newly added $M S$ estimates for the period from 1964 to 1977 and beyond (Storchak et al. 2017). During the period 1978-2010, the mean difference between the original and rebuilt $M S$ is $-0.01 \pm 0.11$, i.e. on average, the rebuilt $M S$ is 0.01 units of magnitude larger than the original $M S$.

Figure 14 shows the timeline of improvement in the number of seismic arrivals associated to events in the ISC Bulletin. The year 1999 appears most "fruitful", where the number of arrivals has increased by $100 \%$. The latter is a result of several additional reports received at the ISC, with the largest single new contributor in that year being the meteorological bureau in Taipei (CWB) that reported to the ISC the entire catalogue of the $1999 M_{W} 7.6$ Chi-Chi earthquake sequence. In the past, CWB reported seismic arrivals just for those earthquakes that were felt. We have now included into the rebuilt ISC Bulletin the entire CWB catalogue 


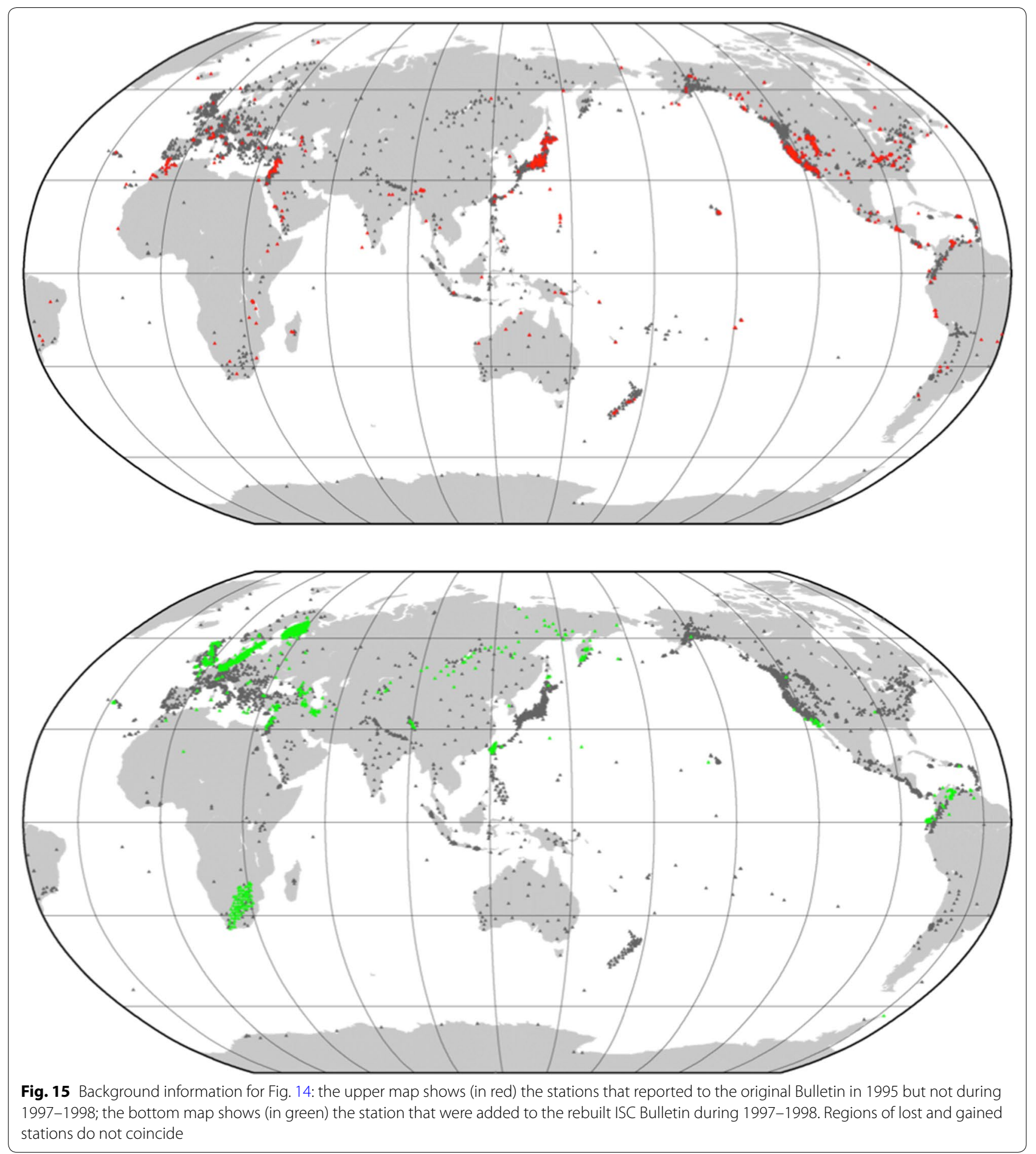

complete with station arrivals from data year 1991 to present. Two other large additions for data year 1999 were some station arrival time data from Japan's JMA and Russia's GS RAS that appear to have been accidentally left out of the original Bulletin due to teething problems whilst introducing the relational database into ISC operations. Data year 1999 was in fact the first data year produced using a database. Binary electronic files (so-called working tape files) were used in the past to process and store the ISC Bulletin information. 
Table 1 Comparative analysis of rebuild versus original ISC Bulletin (1964-2010)

\begin{tabular}{lccc}
\hline Parameters & Original ISC Bulletin & Rebuilt ISC Bulletin & Change \\
\hline Events & $3,983,461$ & $4,451,492$ & $+12 \%$ \\
ISC hypocentres & $1,122,279$ & 556,135 & $-50 \%$ \\
ISC mb & 481,169 & 395,270 & $-18 \%$ \\
ISC MS & 103,596 & 77,397 & $-25 \%$ \\
Arrivals & $96,283,793$ & $112,601,632$ & $+17 \%$ \\
Stations & 12,817 & 15,559 & $+21 \%$ \\
\hline
\end{tabular}

The annual station numbers (also in Fig. 14) show an improvement in the rebuilt ISC Bulletin as compared to the original Bulletin for every single data year. An apparent drop in the number of arrivals in the original Bulletin during the period 1997-1998 appears to be "compensated" by the additional arrivals added to the rebuilt bulletin. This compensation though is not quite equivalent, as a general loss of reports from $\sim 500$ stations worldwide in the original Bulletin merely coincided with the addition of station reports to the rebuilt Bulletin in entirely different areas, often as part of temporary deployments (Fig. 15).

Overall, data from 2742 new stations (an increase of $\sim 21 \%$ ) have been added into the rebuilt ISC Bulletin during the period 1964-2010.

Finally, Table 1 summarises the changes in overall numbers in the rebuilt ISC Bulletin for the period 19642010. The overall numbers of events, seismic arrivals and stations have increased. The numbers of ISC hypocentres and magnitudes have gone down, whilst many local agency hypocentre solutions have taken their place as primary.

\section{Conclusions}

This has been a unique project. Never in its entire 55-year history has the ISC been able to critically review, update and extend its already published Bulletin. The work to obtain additional funding, design criteria and procedures, plan the details, run automatic procedures and manually review the results has taken more than 11 years and a large fraction of the ISC staff time.

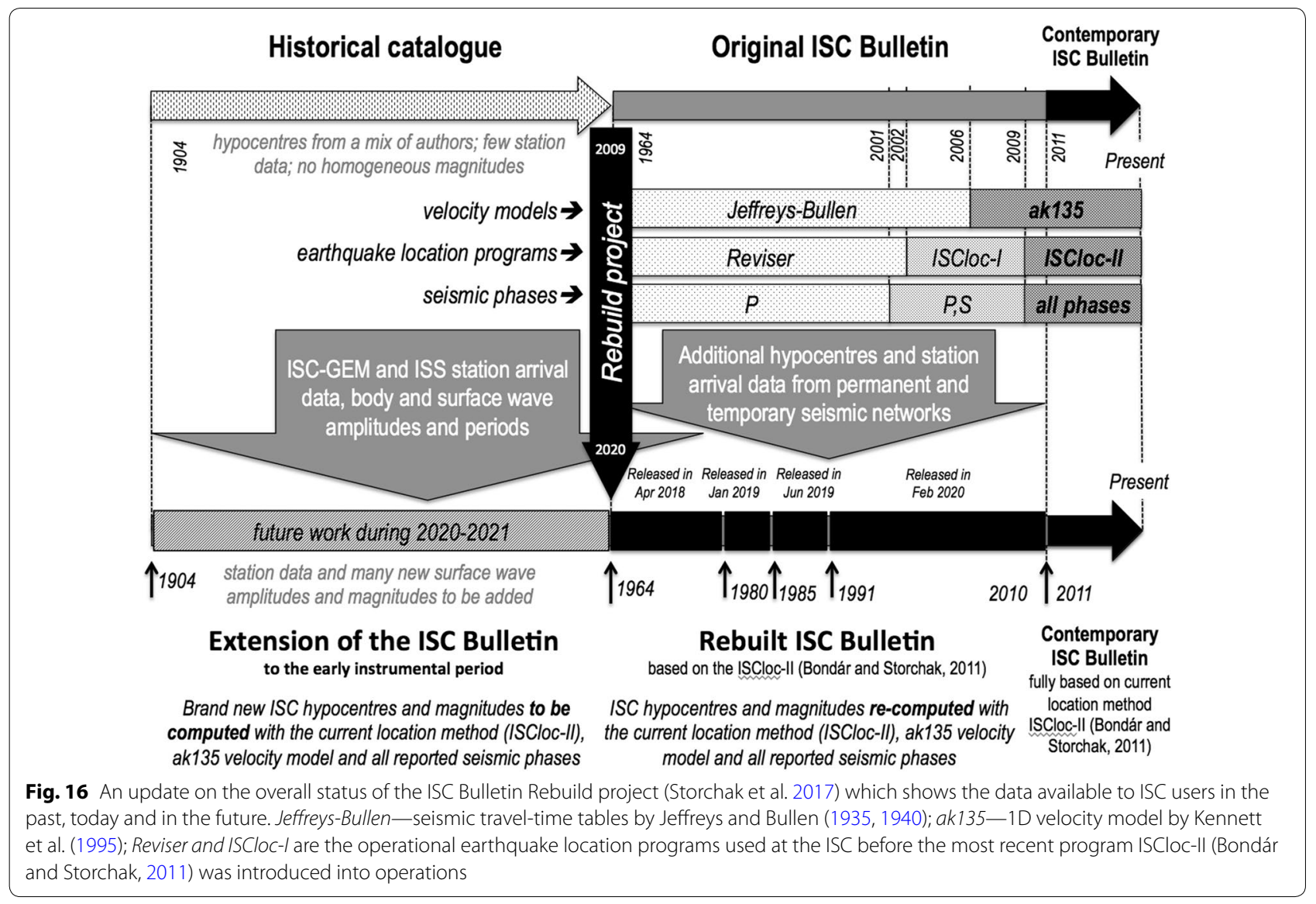


The ISC Bulletin available from the ISC website today has been completely rebuilt for the 1964-2010 period (Fig. 16). As a result:

- A considerable number of poorly constrained or phantom events has been removed from the ISC Bulletin;

- All ISC hypocentre solutions are now based on the ak135 velocity model (Kennet et al. 1995) where Jeffreys-Bullen travel-time tables (Jeffreys and Bullen 1935, 1940) were previously used for decades;

- All ISC hypocentres and magnitudes currently available to users are now mutually consistent (1964-present) because they have been computed using the same technique currently used in ISC operations; the ISC hypocentres are less biased by the uneven distribution of stations in source-to-station azimuth;

- The variety of general default depths, used in the original ISC Bulletin have been modified to those region-specific default depths described by Bondár and Storchak (2011);

- The rebuilt ISC $m b$ and MS magnitudes and their uncertainties are more robust;

- A considerable number of ISC magnitudes based on only one or two stations have been removed from the Bulletin;

- $M S$ magnitude estimates are now available for the period 1964-1977;

- We noted small changes in average $m b$ and $M S$ that should be taken into account in studies of seismic hazard;

- A considerable amount of previously unavailable data from 90 permanent and temporary seismic deployments have been added to the Bulletin;

- We critically reviewed relocated hypocentres and recomputed magnitudes of seismic events where they deviated to a considerable degree from the original (historical) reviewed ISC solutions or where no good fit to reported station data was detected; all other ISC solutions remained as determined by automatic procedures.

\section{Future work}

This was the first, but not the last, rebuild of the ISC Bulletin. Similar projects will no doubt follow in the future as better location techniques, more adequate global velocity models and better data become available.

The improvement in the ISC Bulletin will soon be translated into other ISC products, such as the IASPEI
Reference Event List (GT), ISC-EHB dataset, ISC-GEM catalogue and ISC Event Bibliography (International Seismological Centre 2020d, e, f, g).

As the next step (Fig. 16), we now aim to extend the ISC Bulletin into the early instrumental period (19041963), based on the existing data in the ISC database and data from BAAS, ISS, BCIS and other sources, collected and digitised during the work on the ISC-GEM catalogue (Di Giacomo et al. 2015, 2018).

\section{Remarks}

We admire the work accomplished by generations of ISC seismologists and data-reporting agencies since 1964, when patterns of seismicity were not known as accurately as they are today. Most of the work, accomplished recently, was in fact almost impossible to accomplish even 20 years ago, before powerful computers, database software and modern ways of exhibiting the catalogue data graphically and interactively became available.

\section{Abbreviations}

ak135: Seismic velocity model by Kennett et al. (1995); BAAS: British Association for the Advancement of Science (1900-1912,1913-1917); BCIS: Bureau Central International de Sismologie, Strasbourg, France; CTBTO: Comprehensive nuclear Test Ban Treaty Organization, Vienna, Austria; CWB: Central Weather Bureau, Chinese Taipei; EHB: Engdahl, van der Hilst and Buland catalog (Engdahl 1998); GS RAS: Geophysical Survey of the Russian Academy of Sciences, Obninsk, Russia; GT: Ground Truth; IASPEl: International Association of Seismology and Physics of the Earth Interior; IDC: International Data Centre, a division of CTBTO; IRIS: Incorporated Research Institutions for Seismology; ISC: International Seismological Centre, Thatcham, United Kingdom; ISS: International Seismological Summary (1918-1963); JB: Jeffreys-Bulletin travel-time tables (Jeffreys and Bullen 1935, 1940); JMA: Japan Meteorological Agency; KOERI: Kandilli Observatory and Earthquake Research Institute, Istanbul, Turkey; LAO: Montana Large Aperture Seismic Array, USA (Matkins 1973); NEIC: National Earthquake Information Center of USGS; PIDC: Prototype International Data Centre, Arlington, USA; USGS: United States Geological Survey.

\section{Acknowledgements}

We acknowledge the work of approximately 150 agencies in approximately 100 countries that install and run permanent seismic networks, process waveform data and report seismic bulletins to the ISC on a regular basis. Many of them have been contributing data to the ISC for many tens of years, some, from the beginning of the Twentieth Century.

We are grateful to many colleagues worldwide who provided numerous, large and small contributions of previously missing data to be integrated into the rebuilt ISC Bulletin [see the Appendix in this article and also in Storchak et al. (2017)]

We acknowledge a great input to the success of this project from István Bondár, whose work at the ISC during 2008-2014 led to the design, implementation and testing of the current advanced ISC earthquake location program. We thank Ray Willemann for his initiative in continuing to source and collect historical bulletin data even though the standard ISC analysis of the corresponding time periods had been completed. We thank Wayne Richardson for his meticulous work on cleaning up the ISC Bulletin from various artefacts, including hundreds of out-dated or incomplete seismic phase names reported to the ISC over the years. We thank Przemyslaw Ozgo for building a specialised on-screen application that the ISC analysts used for the review of the rebuilt ISC Bulletin. We thank Silvana Jacob, a student of University of Potsdam in Germany, who picked seismic phases using waveforms of two temporary deployments: INDEPTH (Himalaya-Tibet) and BANJO and SEDA (central Andean Cordillera of Bolivia and northern Chile) during her work placement 
at the ISC in 2012. We are grateful to Emily Delahaye for training new analysts for the work on the Rebuild project and to John Eve for occasional help in pars ing historical data into the database. We are also grateful to Robin Adams for useful insights into early earthquake processing procedures used at the ISC. We thank Edith Korger for her work on reviewing relevant scientific publications, getting in touch with the authors and bringing new bulletin datasets to the ISC. We are indebted to Lynn Elms for careful review of the manuscript and help in administration of funds and personnel. We also thank Maureen Aspinwall for her help in administering the project funding and reports to funding agencies during her time at the ISC.

We are especially grateful to other ISC Analysts: Elizabeth Ayres, Emily Delahaye, Charikleia Gkarlaouni, Baokun Li, Burak Sakarya and Rebecca Verney who gave this project a great deal of their time and attention. We also thank Rosemary Hulin and Peter Franek for taking on the major workload of analysing the contemporary ISC Bulletin whilst the rest of the Analyst team was busy finishing the Rebuild project in late 2019 and early 2020.

Finally, we acknowledge the use of waveform data, services and software from IRIS, Google Maps and Generic Mapping Tool (GMT, Wessel et al. 2019).

We declare that all authors have approved the manuscript for submission to Geoscience Letters. We also declare that none of the content of the manuscript has been published or submitted for any other publication.

\section{Authors' contributions}

DAS has prepared the manuscript and is the first author. JH, DAS and LB worked out the principles and methods of earthquake selection for relocation and review and took part in the overall bulletin integrity check. JH managed the database for this project and prepared a large fraction of the figures. DAS worked on identifying and sourcing additional historical data to the ISC database. DAS also worked to obtain the funding that allowed employment of additional staff at the ISC. LB, KL, BS and the entire ISC Analyst team have all put a lot of time into the review of the rebuilt ISC Bulletin. DAS reviewed the data month of July 1965. LB managed the work of all ISC Analysts, passing his duties to $\mathrm{KL}$ a few months before the end of the project. DDG helped make an overall bulletin check, especially as far as ISC magnitudes are concerned, and took part in many discussions over the course of the project. All authors read and approved the final manuscript.

\section{Funding}

We thank 72 Member-Institutions of the ISC in 48 countries, 150 data providers and several grantors and sponsoring organizations, including Comprehensive nuclear Test Ban Treaty Organization (CTBTO), FM Global, the Lighthill Risk Network, United States Geological Survey (USGS), National Science Foundation (NSF) and Federal Institute for Geosciences and Natural Resources (BGR) for providing critical funding for extending the ISC mission. In particular, we acknowledge the NSF Awards 1811737, 1417970 and 0949072; USGS Awards G14AC00149, G15AC00202, G18AP00035 and G19AS00033.

The ISC is also sponsored by Reftek Systems Inc., Guralp Systems, GeoSIG, TAIDE Enterprise Co, Seismology Research Centre (SRC, Australia) and MS\&AD InterRisk Research \& Consulting.

\section{Availability of data and materials}

The ISC Bulletin data are openly available via several search mechanisms at the ISC website (https://www.isc.ac.uk/iscbulletin/search/) as well as from the ISC $\mathrm{ftp}$-site and DVD-ROMs. In particular, at the time of this article publication, the data of the rebuilt ISC Bulletin have already replaced the original ISC Bulletin in the main ISC database.

The data from the original ISC Bulletin once served as an indispensable source of knowledge and information that was collected based on the widest possible international collaboration of seismic monitoring experts around the world. Although we believe that all useful information from the original Bulletin was preserved in the rebuilt Bulletin, it is sometimes necessary for researchers to obtain data as they were published in the original ISC Bulletin and used by researchers in historical scientific publications. We therefore preserved copies of the original ISC Bulletin in several different formats and made them available from the ISC ftp-site in the form of historical digital files: ftp://isc-mirror.iris.washington.edu/pub/prerebuild/.

\section{Competing interests}

We declare that none of the authors have any competing interest in this publication.

\section{Author details}

${ }^{1}$ International Seismological Centre, Pipers Lane, Thatcham RG19 4NS, Berkshire, UK. ${ }^{2}$ Department of Physics, University of Alberta, Edmonton, AB T6G2E1, Canada.

\section{Appendix}

Below we present a list of additional seismic bulletin contributions received and included in the ISC Bulletin during the Rebuild project for the period 1980-2010. They are noted with a set of agency codes in Fig. 2. The black bars show the time span for each dataset included during this part of the Rebuild project. Some of these datasets span over larger period of time and we dealt with them accordingly.

Each dataset was integrated either on behalf of an agency (institution). Alternatively, an agency code was invented to represent a particular book, publication or an experiment. Below we acknowledged the work of a particular individual scientist who corresponded with the ISC and helped to integrate each dataset. This does not in any way diminish the contribution of other scientists and institutions that were involved in the project. Full set of acknowledgements is to be found in scientific publications that we referenced below.

AFUA-teleseismic arrival times from Africa Array, courtesy of Samantha Hansen of University of Alabama and Andrew Nyblade of Penn State University, USA (Hansen and Nyblade 2013).

ASIES-recomputed set of AutoBATS MT (Jian et al. 2018) moment tensor solutions in place of BATS CMT from the Institute of Earth Sciences of Academia Sinica, Taipei.

AWI-local/regional events in Antarctica and previously overlooked data, courtesy of Tanja Fromm and Alfons Eckstaller (Eckstaller et al. 1997), Alfred Wegener Institute for Polar and Marine Research, Germany.

AWI-focal mechanisms for earthquakes in the Gulf of Cadiz (Geissler et al. 2010), courtesy of Wolfram Geissler, Alfred Wegener Institute for Polar and Marine Research, Germany.

BER-hypocentres and arrival times for local earthquakes in Western Hellenic Subduction Zone recorded at permanent and temporary stations (MEDUSA) deployed across Greece and neighboring countries (Halpaap et al. 2018), courtesy of Felix Halpaap, Stéphane Rondenay and Lars Ottemöller, University of Bergen, Norway.

BUD-moment tensors, hypocentres and station arrivals from a temporary network in Pannonia Basin (Weber, 2016), courtesy of Zoltan Weber, Koevesligethy Rado Seismological Observatory, Hungary.

BUEE-earthquake bulletin from TUCAN deployment in Costa Rica and Nicaragua (Syracuse et al. 2008), courtesy of Geoffrey Abers, Cornell University, USA; 
BYKL-bulletin of the 14 largest earthquakes recorded by temporary network during 1979-1992 period in the region of Severo-Mujskij tunnel on the Trans-Siberian railway (Golenetsky et al. 1985; Kochetkov et al. 1987), courtesy of Nadezhda Gileva, Baykal Regional Seismological Centre, Geophysical Survey of Russian Academy of Sciences, Irkutsk, Russia.

CERI-locations and station readings of earthquakes in central New Madrid seismic zone during PANDA array deployment (Chiu et al. 1992), courtesy of JerMing Chiu, Memphis University, USA.

CLL (ATH, BCIS, CLL, NEIC, UPP, WAR)-historical earthquake bulletins, courtesy of Seigefried Wendt, Collm Observatory, Germany.

CUPWA-bulletin of earthquakes in Western Australia, courtesy of Vic Dent, private researcher, Australia.

EAF-previously missing part of regular data from Eastern and Southern Africa Regional Seismological Working Group (ESARSWG), courtesy of Atalay Ayele, Addis Ababa University, Ethiopia.

EAGLE-bulletin of earthquakes from the Ethiopian Afar Geoscientific Lithospheric.

Experiment (EAGLE) (Keir et al. 2006).

ECX-historical bulletin of earthquakes in Mexico by the Centro de Investigación Científica y de Educación Superior de Ensenada (CICESE), courtesy of Alejandra Nunex and Raoul Castro Escamilla, personal communication, 2016.

ECX-bulletins for 2010 El Mayor-Cucapah aftershock sequence (Castro et al. 2011), courtesy of Raoul Castro Escamilla.

EUROP - a set of accurate absolute arrival times for stations in Europe which do not report to the ISC (Amaru et al. 2008), courtesy of the ORFEUS Data Centre.

FUBES-catalogue of earthquakes recorded by two temporary deployments in Iquique/Chile (Bloch et al. 2014), courtesy of Wasja Bloch, Freie Universität Berlin, Germany.

GCMT (GCMT, HRVD, IDC, NEIC, NEIS)-The Global Centroid-Moment-Tensor (CMT) Project at the LamontDoherty Earth Observatory of Columbia University (2006-present); previously at Harvard University (19822006) (Ekström et al. 2012; Dziewonski et al. 1981).

GEOAZ-bulletin data from temporary deployment SUBLIME in Esmeraldas area of northern Ecuador (Pontoise and Monfret 2004), courtesy of Tony Monfret of CNRS-Géoazur, France.

GEOMR-bulletin of temporary Maule aftershock deployment in Chile (Lieser et al. 2014), courtesy of Kathrin Lieser, International Seismological Centre, formerly at GEOMAR, Helmholtz-Zentrum für Ozeanforschung, Kiel, Germany.
GEOMR-bulletin from an offshore-onshore seismic network in Western Mediterranean (Grevemeyer et al. 2015), courtesy of Ingo Grevemeyer, GEOMAR Helmholtz-Zentrum für Ozeanforschung, Kiel, Germany.

GII-historical bulletins, courtesy of Lea Feldman, Geophysical Institute of Israel.

GSET2-dataset from GSETT-2 (The Group of Scientific Experts Second Technical Test) experiment that contains parametric data from $\sim 3000$ seismic events as recorded by $\sim 60$ globally distributed stations, courtesy of Johannes Schweitzer, NORSAR, Norway.

HIMNT-arrival times, hypocentres and moment tensors based on the Himalayan Nepal Tibet Seismic Experiment (HIMNT) (De La Torre et al. 2007), courtesy of Thomas de la Torres and Anne Sheehan, University of Colorado Boulder, USA.

HLW - moment tensors for earthquakes in Iran, courtesy of Ahmed Hosny Ali, National Research Institute of Astronomy and Geophysics (NRIAG), Helwan, Egypt.

HNR-historical paper-based arrival times at station Honiara, Solomon Islands, entered into the database at the ISC.

IAG-moment tensor solutions for Iberia-Maghreb earthquakes (Stich et al. 2010), courtesy of Daniel Stich, Instituto Andaluz de Geofisica University of Granada, Spain.

IAG-moment tensor solutions for Iberia-Maghreb earthquakes (Martin et al. 2015), courtesy of Rosa Martín, Instituto Andaluz de Geofisica University of Granada, Spain.

IASBS-bulletin of hand-picked earthquakes in selected regions of Iran (Ghods and Sobouti, 2005; Ghods et al. 2012), courtesy of Abdolreza Ghods, Institute for Advanced Studies in Basic Sciences, Zanjan, Iran.

IEC-arrival times of seismic waves generated by peaceful nuclear explosions and recorded by stations of Baykal network (Dobrynina et al. 2019), courtesy of Anna Dobrynina, Institute of the Earth Crust, Russian Academy of Sciences, Irkutsk, Russia.

IEPN -arrival times from station KHE (Morozov et al. 2018), courtesy of Alexey Morozov, Institute of Environmental Problems of the North, Russian Academy of Sciences, Arkhangelsk, Russia and the archive of the Geophysical Survey of Russian Academy of Sciences (https://www.ceme.gsras.ru/new/eng/ssd_news.htm).

IFREE-arrival time data from the Ocean Hemisphere Network Project (OHP), courtesy of Yoshio Fukao and Daisuke Suetsugu, Institute for Research on Earth Evolution, Japan Agency for Marine-Earth Science and Technology, Yokosuka, Japan.

IGGSL-bulletins of stations of NECsaids Array in North East China (Wang et al. 2016), courtesy of Yinshuang $\mathrm{Ai}$ and Yuan Ling, Seismology Lab, Institute of 
Geology and Geophysics, Chinese Academy of Sciences, Beijing, China.

IGIL-focal mechanisms of earthquakes in Southwest Iberia and Azores (Custodio et al. 2016), courtesy of Susana Custodio, Instituto Dom Luiz, University of Lisbon, Portugal.

IGIL-bulletin and moment tensors of earthquakes in Cape Verde (Vales et al. 2014), courtesy of Graça Silveira, Instituto Dom Luiz, University of Lisbon, Portugal.

INMG - bulletins from temporary deployment NEAREST in the Gulf of Cadiz (Romsdorf, 2010; Silva et al. 2017), courtesy of Sonia Manzoni and Stephen Monna, the Portuguese Institute for Sea and Atmosphere (IPMA), Lisbon, Portugal.

IPGP-bulletin of offshore- onshore deployment in Vanuatu (Baillard et al. 2015); courtesy of Christian Baillard, Institut de Physique du Globe de Paris, France.

ISC-EHB - the entire EHB catalogue (Engdahl et al. 1998) has been replaced with the hypocentre solutions from the ISC-EHB dataset (Weston et al. 2018; Engdahl et al. 2020).

ISC-GEM-basic seismic measurement data digitised from the original station and network bulletins at the ISC during the ISC-GEM project (Di Giacomo et al. 2015);

ITU-earthquake source mechanisms of earthquakes in the Hellenic trench near Crete (Taymaz et al. 1990), courtesy of Tuncay Taymaz, Istanbul Technical University.

JEN-historical station bulletins of Geodynamic Observatory Moxa, Friedrich-Schiller-Universitat, Jena, Germany.

KUK-bulletin data from Geological Survey Department, Accra, Ghana.

MOS-historical database of the Geophysical Survey of Russian Academy of Sciences, Obninsk, courtesy of Alexey Malovichko, Vera Babkina and Irina Gabsatarova, personal communication, 2012.

MSUGS (original data by: AEIC, ASRS, AVETI, BYKL, CSEM, DNAG, DRS, EIDC, JMA, KOLA, KRSC, MAT, MATSS, MOS, MSUGS, NEIC, NERS, NORS, IDC, SBDV, SKHL, WASN, YARS, ZEMSU, ZUR; agency codes are available at https://www.isc.ac.uk/iscbulletin/ agencies) - integrated collection of digitised earthquake bulletins of regional seismic networks and several scientific publications, covering the eastern part of Russia, courtesy of Kevin Mackey, Michigan State University (Mackey et al. 2003, 2010).

NAO-bulletins for early years of NORSAR array, Norway; courtesy of Johannes Schweitzer, personal communication, 2017.

OGAUC-focal mechanisms of earthquakes in the southwest of Iberia (Domingues et al. 2013), courtesy of Susanna Custodio of Centro de Investigação da Terra e do Espaço da Universidade de Coimbra, Portugal.
RSNC - historical bulletins of earthquakes in Colombia, courtesy of Patricia Pedraza García, Red Sismológica Nacional de Colombia, Servicio Geológico Colombiano, Bogota, Colombia.

SCSIO-relocation of two earthquakes at southwestern Indian ridge, by combining the land-based data with the data of temporary OBS deployment (Luo et al. 2017), courtesy of Minghuo Zhang, Institute of Oceanology, Chinese Academy of Sciences, Guangzhou, China.

SEA-bulletin with corrected amplitude readings submitted in place of earlier version, courtesy of Peter Burkholder, Ken Creager, Wallis Hutton and Peter Benson (University of Washington, Geophysics Program) and Rick Benson (IRIS DMC);

SIO-station arrival time picks in Hawaii OSNPE (Sutherland et al. 2004), courtesy of Frank Vernon, Scripps Institution for Oceanography, San Diego, USA.

SPITAK-bulletin of the aftershock deployment following the 1988 Spitak earthquake in Armenia (Arefiev et al. 1991), courtesy of Vera Bykova, Institute of Physics of the Earth, Russian Academy of Sciences, Moscow, Russia.

SYO-historical bulletins of Syowa Base in Antarctica (Iwata and Kanao, 2015; Storchak et al. 2015), courtesy of Masaki Kanao and Ayuko Ibaraki, National Institute of Polar Research (NIPR), Tachikawa, Japan;

TAN-bulletins of earthquakes in Madagascar, courtesy of Tsiriandrimanana (Tsitsi) Rakotondraibe, Institute and Observatory of Geophysics, University of Antananarivo, Madagascar.

TAP-complete Taiwan earthquake bulletins from CWB; previously, station arrival data were given only for felt earthquakes.

UAF-moment tensors of earthquakes in Bolivia (Alvizuri and Tape 2016), central (Tape et al. 2015) and southern Alaska (Silwal and Tape 2016), courtesy of Carl Tape, University of Alaska Fairbanks, USA.

UATDG - catalogue of earthquakes in Central Chile, CHARGE experiment (Wagner et al. 2005; Anderson et al. 2007) courtesy of Megan Anderson and Lara Wagner, University of Arizona, Tucson, USA.

UAV-previously missing part of the earthquake bulletin of the Andes, courtesy of Martin Rengifo, Universidad de Los Andes, La Hechicera, Mérida, Venezuela.

UCB - bulletins of earthquakes of the Rocky Mountains and Rio Grande Rift from EarthScope Transportable Array and CREST temporary deployment (Nakai et al. 2017), courtesy of Anne Sheehan and Jenny Nakai, University of Colorado, Boulder, USA.

UCDES-focal mechanisms for earthquakes of South Caspian region (Priestley et al. 1994), courtesy of Keith Priestley, University of Cambridge, Department of Earth Sciences, Cambridge, United Kingdom; 
UCSC - bulletin of earthquakes in Costa Rica, CRSEIZE experiment (Moore-Driskell et al. 2013), courtesy of Heather de Shon and Melissa Moore-Driskell, University of Memphis, USA.

UESG-moment tensors of earthquakes in Aleutian Islands (Liakopoulou-Morris et al. 1995), courtesy of Ian Main, University of Edinburgh, UK.

ULE-bulletin of earthquakes in Afar, Ethiopia (Keir et al. 2009; Stork et al. 2013), courtesy of Derek Keir and Anna Stork, University of Leeds, UK.

UPIES-moment tensors for earthquakes in Baladeh sequence in Albortz Mountains, Iran (Donner et al. 2013) and earthquake doublet in northwest Iran (Donner et al. 2015), courtesy of Stefanie Donner, University of Potsdam, Germany.

UREES-bulletins of earthquakes in Afar (Ebinger et al. 2008; Keir et al. 2009; Belachew et al. 2011), courtesy of Cynthia Ebinger of University of Rochester, UK and Derek Keir, University of Southampton, UK.

UTEP_-bulletin of earthquakes in Butan (Velasco et al. 2007), courtesy of Aaron Valasco, University of Texas in El Paso, USA.

UWMDG-earthquake bulletin and moment tensors from Darfiled, New Zealand (Syracuse et al. 2012, 2013), courtesy of Ellen Syracuse, University of Wisconsin-Madison, USA.

VSI-bulletin of Athens 1999 aftershock sequence (Pirli, 2001), courtesy of Myrto Pirli, independent researcher.

WEL-update of the bulletin of the New Zealand seismic network, GNS Science, 2014, courtesy of Kevin Fenaughty, personal communication, 2014.

WUSTL-bulletin of earthquakes in Mariana islands, recorded by land and ocean bottom seismographs (Heeszel et al. 2008), courtesy of Doug Wiens, Washington University in St. Luis, USA.

WUSTL-bulletin of earthquakes in Fiji-Tonga area (SPaSE and LABATTS projects) (Koper et al. 1998), courtesy of Doug Wiens, Washington University in St. Luis, USA.

Received: 11 August 2020 Accepted: 7 October 2020

Published online: 07 November 2020

\section{References}

Adams RD, Hughes AA, McGregor DM (1982) Analysis procedures at the International Seismological Centre. Phys Earth Planet Inter 30:85-93

Alvizuri C, Tape C (2016) Full moment tensors for small events $(\mathrm{Mw}<3)$ at Uturuncu volcano, Bolivia. Geophys J Int 206(3):1761-1783. https://doi. org/10.1093/gji/ggw247

Amaru ML, Spakman W, Villaseñor A, Sandoval S, Kissling E (2008) A new absolute arrival time data set for Europe. Geophys J Int 173(2):465-472. https ://doi.org/10.1111/j.1365-246X.2008.03704.x
Anderson M, Alvarado P, Zandt G, Beck S (2007) Geometry and brittle deformation of the subducting Nazca Plate, Central Chile and Argentina. Geophys J Int 171(1):419-434. https://doi.org/10.1111/j.1365-246X.2007.03483.x

Arefiev S, Aptekman J, Afimina T, Gabsatarova I, Geodakian E, Zakharova A, Lander A, Pletnev K, Tatevossian R, Shebalin N, Shilova N, Dorbath L, Dorbath C, Cisternas A, Haessler H, Rivera L (1991) Catalogue of aftershocks of the Spitak earthquake, December 7, 1988. Izvestiya Phys Solid Earth $11: 60-73$

BAAS (1900-1912) British Association for the Advancement of Science, Circulars 1-27 issued by the Seismological Committee of the British Association for the Advancement of Science (Shide Circulars)

BAAS (1913-1917) British Association for the Advancement of Science, Seismological Committee, monthly bulletins

Baillard C, Crawford WC, Ballu V, Régnier M, Pelletier B, Garaebiti E (2015) Seismicity and shallow slab geometry in the central Vanuatu subduction zone. J Geophys Res Solid Earth 120:5606-5623. https://doi. org/10.1002/2014JB011853

Belachew M, Ebinger C, Coté D, Keir D, Rowland JV, Hammond JOS, Ayele A (2011) Comparison of dike intrusions in an incipient seafloor-spreading segment in Afar, Ethiopia: Seismicity perspectives. J Geophys Res 116:B06405. https://doi.org/10.1029/2010JB007908

Bloch W, Kummerow J, Salazar P, Wigger P, Shapiro SA (2014) High-resolution image of the North Chilean subduction zone: seismicity, reflectivity and fluids. Geophys J Int 197(3):1744-1749. https://doi.org/10.1093/gji/ggu08 4

Bondár I, Storchak DA (2011) Improved location procedures at the International Seismological Centre. Geophys J Int 186:1220-1244. https://doi. org/10.1111/j.1365-246X.2011.05107.x

Castro RR, Acosta JG, Wong VM, Pérez-Vertti A, Mendoza A, Inzunza L (2011) Location of aftershocks of the 4 April 2010 Mw 7.2 El Mayor-Cucapah earthquake of Baja California Mexico. Bull Seism Soc Am 101(6):30723080. https://doi.org/10.1785/0120110112

Chiu JM, Johnston AC, Yang YT (1992) Imaging the active faults of the Central New Madrid Seismic Zone using PANDA array data. Seism Res Let 63(3):375-393. https://doi.org/10.1785/gssrl.63.375

Custodio S, Lima V, Vales D, Cesca S, Carrilho F (2016) Imaging active faulting in a region of distributed deformation from the joint clustering of focal mechanisms and hypocentres: application to the Azores-Western Mediterranean region. Tectonophysics 676(4):70-89. https://doi.org/10.1016/j. tecto.2016.03.013

De La Torre TL, Monsalve G, Sheehan AF, Sapkota S, Wu F (2007) Earthquake processes of the Himalayan collision zone in eastern Nepal and the southern Tibetan Plateau. Geophys J Int 171(2):718-738. https://doi org/10.1111/j.1365-246X.2007.03537.x\n

Di Giacomo D, Harris J, Villaseñor A, Storchak DA, Engdahl ER, Lee WHK, the Data Entry Team (2015) ISC-GEM: Global Instrumental Earthquake Catalogue (1900-2009), I Data collection from early instrumental seismological bulletins. Phys Earth Planet Int 239:14-24. https://doi.org/10.1016/j. pepi.2014.06.003

Di Giacomo D, Engdahl ER, Storchak DA (2018) The ISC-GEM Earthquake Catalogue (1904-2014): status after the Extension Project. Earth Syst Sci Data 10:1877-1899. https://doi.org/10.5194/essd-10-1877-2018

Domingues A, Custodio S, Cesca S (2013) Waveform inversion of small to moderate earthquakes located offshore southwest Iberia. Geophys J Int 192:248-259. https://doi.org/10.1093/gji/ggs010

Dobrynina AA, Sankov VA, Chechelnitskiy VV (2019) Underground nuclear explosions in Eastern Siberia and the Sakha Republic: preliminary results of seismogram analysis based on Baikal seismic stations network. NNC RK Bulletin 2(78):21-27

Donner S, Roessler D, Krueger F, Ghods A, Strecker MR (2013) Segmented seismicity of the Mw 6.2 Baladeh earthquake sequence (Alborz Mountains, Iran) revealed from regional moment tensors. J Seismol. 17(3):925-959. https://doi.org/10.1007/s1095001393627

Donner S, Ghods A, Krueger F, Roessler D, Landgraf A, Ballato P (2015) The Ahar-Varzeghan earthquake doublet (Mw 6.4 and 6.2) of 11 August 2012: regional seismic moment tensors and a seismotectonic interpretation. Bull Seism Soc Am 105(2A):791-807. https://doi.org/10.1785/0120140042

Dziewonski AM, Chou T-A, Woodhouse JH (1981) Determination of earthquake source parameters from waveform data for studies of global and regional seismicity. J Geophys Res 86:2825-2852. https://doi.org/10.1029/JB086 iB04p02825 
Ebinger C, Keir D, Ayele A, Belachew M, Calais E, Wright T, Campbell E, Buck R (2008) Capturing magma intrusion and faulting processes in a zone of continental rupture: Seismicity of the Dabbahu (Afar) rift. Geophys J Int 174(3):1138-1152. https://doi.org/10.1111/j.1365246X.2008.03877.x

Eckstaller A, Schmidt T, Gaw V, Muller C, Rogenhagen J (1997) The Geophysical Observatory at Neumayer Station, Antarctica Geomagnetic and Seismological Observations. Ber Polarforsch 244:141 (ISSN 0176-5027)

Ekström G, Nettles M, Dziewonski AM (2012) The global CMT project 2004-2010: Centroid-moment tensors for 13,017 earthquakes. Phys Earth Planet Inter 200-201:1-9. https://doi.org/10.1016/j.pepi.2012.04.002

Engdahl ER, van der Hilst R, Buland R (1998) Global teleseismic earthquake relocation with improved travel times and procedures for depth determination. Bull Seism Soc Am 88(3):722-743

Engdahl ER, Di Giacomo D, Sakarya B, Gkarlaouni CG, Harris J, Storchak DA (2020) ISC-EHB 1964-2016, an improved data set for studies of earth structure and global seismicity. Earth Space Sci. https://doi. org/10.1029/2019EA000897

Flinn EA, Engdahl ER, Hill AR (1974) Seismic and geographical regionalization. Bull Seism Soc Am 64(3-2):771-992

Geissler WH, Matias L, Stich D, Carrilho F, Jokat W, Monna S, IbenBrahim A, Mancilla F, Gutscher M-A, Sallarès V, Zitellini N (2010) Focal mechanisms for sub-crustal earthquakes in the Gulf of Cadiz from a dense OBS deployment. Geophys Res Lett 37:L18309. https://doi.org/10.1029/2010GL0442 89

Ghods A, Sobouti F (2005) Quality assessment of seismic recording: Tehran seismic telemetry network. Asian J Earth Sci 25:687-694

Ghods A, Rezapour M, Bergman E, Mortezanejad G, Talebian M (2012) Relocation of the 2006 Mw 6.1 Silakhour, Iran, earthquake sequence: details of fault segmentation on the main recent fault. Bull Seism Soc Am 102:398-416

Golenetsky SI, Kochetkov VM, Solonenko AV, Misharina LA, Borovik NS, Solonenko NV, Gileva NA, Kozmin BM, Anikanova GV, Melnikova VI, Steinman EA, Larionov AG (1985) Geology and Seismicity of the region of Baykal-Amur Railway. Seismicity. Novosibirsk, Nauka (in Russian)

Grevemeyer I, Gracia E, Villasenor A, Leuchters W, Watts AB (2015) Seismicity and active tectonics in the Alboran Sea, Western Mediterranean: constraints from an offshore-onshore seismological network and swath bathymetry data. J Geophys Res 120:8348-8365. https://doi. org/10.1002/2015JB012073

Halpaap F, Rondenay S, Ottemöller L (2018) Seismicity, deformation, and metamorphism in the Western Hellenic Subduction Zone: New constraints from tomography. J Geophys Res Solid Earth 123:3000-3026. https://doi. org/10.1002/2017JB015154

Hansen S, Nyblade A (2013) The deep seismic structure of the Ethiopia/Afar hotspot and the African superplume. Geophys J Int 194:118-124. https:// doi.org/10.1093/gji/ggt116

Heeszel DS, Wiens DA, Shore PJ (2008) Earthquake evidence for along-arc extension in the Mariana Islands. Geophys Geosys Geochem. https://doi. org/10.1029/2008GC002186

International Seismological Centre (2020a) On-line Bulletin. International Seismological Centre, Thatcham. https://doi.org/10.31905/D808B830

International Seismological Centre (2020b) Summary of the Bulletin of the International Seismological Centre, January-June 2017. Summ Bull Int Seismol Centre. https://doi.org/10.31905/JTSXF67S

International Seismological Centre (2020c) International Seismograph Station Registry (IR). International Seismological Centre, Thatcham. https://doi. org/10.31905/EL3FQQ40

International Seismological Centre (2020d) IASPEI reference event (GT) list. International Seismological Centre, Thatcham. https://doi.org/10.31905 /32NSJF7V

International Seismological Centre (2020e) ISC-EHB dataset. International Seismological Centre, Thatcham. https://doi.org/10.31905/PY08W6S3

International Seismological Centre (2020f) ISC-GEM Earthquake Catalogue. International Seismological Centre, Thatcham. https://doi.org/10.31905/ d808b825

International Seismological Centre (2020g) On-line Event Bibliography. International Seismological Centre, Thatcham. https://doi.org/10.31905/ EJ3B5LV6

ISS (1918-1963) International seismological summary, Annual volumes
Iwata T, Kanao M (2015) A quantitative evaluation of the annual variation in teleseismic detection capability at Syowa Station Antarctica. Polar Sci 9(1):26-34. https://doi.org/10.1016/j.polar.2014.10.002

Jeffreys H, Bullen KE (1935) Times of Transmission of Earthquake Waves. Publ Bur Cent Seism Internat 11:3-96

Jeffreys H, Bullen KE (1940) Seismological tables. British Association for the Advancement of Science, London

Jian P-R, Tseng T-L, Liang W-T, Huang P-H (2018) A new automatic full waveform regional moment tensor inversion algorithm and its applications in the Taiwan area. Bull Seism Soc Am 108(2):573-587. https://doi. org/10.1785/0120170231

Keir D, Ebinger CJ, Stuart GW, Daly E, Ayele A (2006) Strain accommodation by magmatism and faulting as rifting proceeds to breakup: Seismicity of the northern Ethiopian rift. J Geophys Res 111:B05314. https://doi. org/10.1029/2005JB003748

Keir D, Hamling I, Ayele A, Calais E, Ebinger C, Wright TJ, Jacques E, Mohamed K, Hammond J, Belachew M, Baker E, Rowland J, Lewi E, Bennati L (2009) Evidence for focused magmatic accretion at segment centers from lateral dike injections captured beneath the Red Sea rift in Afar. Geology 37:59-62. https://doi.org/10.1130/G25147A

Kennett BLN, Engdahl ER, Buland R (1995) Constraints on seismic velocities in the Earth from traveltimes. Geophys J Int 122:108-124

Kochetkov BM, Borovik NS, Misharina LA, Solonenko AV, Anikanova GV, Solonenko NV, Melnikova VI, Gileva NA (1987) Angarsky earthquake swarm in Baykal rift zone (conditions of occurrence and development features). Novosibirsk, Nauka (in Russian)

Koper KD, Wiens DA, Dorman LM, Hildebrand JA, Webb SC (1998) Modeling the Tonga slab: Can travel time data resolve a metastable olivine wedge? J Geophys Res 103(B12):30079-30100. https://doi.org/10.1029/98JB01517

Liakopoulou-Morris F, Main IG, Pearce RG (1995) Source parameters of earthquakes in the Aleutian Islands subduction zone. Geophys J Int 120:419-432. https://doi.org/10.1111/j.1365-246X.1995.tb01829.x

Lieser K, Grevemeyer I, Lange D, Flueh E, Tilmann F, Contreras-Reyes E (2014) Splay fault activity revealed by aftershocks of the $2010 \mathrm{Mw} 8.8$ Maule earthquake, central Chile. Geology 42:823-826. https://doi.org/10.1130/ G35848.1

Luo W, Zhao M, Zhang J, Tao C, Qiu X, Ren Y (2017) Relocation of two earthquakes in the Southwest Indian Ridge area combining land seismic stations' with OBSs' data. Mar Geophys Res 38:27-37. https://doi. org/10.1007/s11001-016-9289-9

Mackey KG, Fujita K, Gounbina L, Koz'min B, Imaev V, Imaeva L, Sedov B, (2003) Explosion contamination of the Northeast Siberian seismicity catalog: implications for natural earthquake distributions and the location of the Tanlu fault in Russia. Bull Seism Soc Am 93:737-746. https://doi. org/10.1785/0120010196

Mackey KG, Fujita K, Hartse HE, Stead RJ, Steck LK, Gunbina LV, Leyshuk N, Shibaev SV, Koz'min BM, Imaev VS, Gordeev El, Chebrov VN, Masal'ski OK, Gileva NA, Bormatov VA, Voitenok AA, Levin YN, Fokina TA (2010) Seismicity Map of Eastern Russia, 1960-2010. Seism Res Let 81(5):761-768

Martín R, Stich D, Morales J, Mancilla F (2015) Moment tensor solutions for the Iberian-Maghreb region during the Iber-Array deployment (2009-2013). Tectonophysics 663:261-274. https://doi.org/10.1016/j.tecto.2015.08.012

Matkins RE (1973) Montana Large Aperture Seismic Array. Final Technical Report, Project VT 2708, National Technical Information Service, US Department of Commerce, 5285 Port Royal Road, Springfield Va. 22151.

Moore-Driskell M, DeShon HR, Rabble W, Thorwart M, Dzierma Y, Arroyo IG (2013) Integration of Arrival-Time Datasets for consistent Quality Control: A Case Study of Amphibious Experiments along the Middle America Trench. Bull Seism Soc Am 103(5):2752-2766. https://doi. org/10.1785/0120120274

Morozov AN, Vaganova NV, Asming VE, Konechnaya YV, Evtyugina ZA (2018) The instrumental seismicity of the Barents and Kara sea region: relocated event catalog from early twentieth century to 1989. J Seismolog 22(5):1171-1209. https://doi.org/10.1007/s10950-018-9760-y

Nakai JS, Sheehan AF, Bilek SL (2017) Seismicity of the rocky mountains and Rio Grande Rift from the EarthScope Transportable Array and CREST temporary seismic networks, 2008-2010. J Geophys Res Solid Earth 122:2173-2192. https://doi.org/10.1002/2016JB013389 
Pirli M (2001) Seismic characteristics of the Athens earthquake aftershock sequence (07/09/1999, Ms = 5.9), MSc Thesis, National and Kapodistrian University of Athens, Athens.

Pontoise B, Monfret T (2004) Shallow seismogenic zone detected from an offshore-onshore temporary seismic network in the Esmeraldas area (northern Ecuador). Geochem Geophys Geosys. https://doi. org/10.1029/2003GC000561

Priestley K, Baker C, Jackson J (1994) Implications of earthquake focal mechanism data for the active tectonics of the south Caspian Basin and surrounding regions. Geophys J Int 118:111-141. https://doi.org/10.1111/ j.1365-246X.1994.tb04679.x

Romsdorf M (2010) Untersuchung zur lokalen Seismizität im Golf von Cadiz. Diploma thesis. Tech. Univ. Bergakademie Freiberg. hdl:10013/epic.37372.

Silva S, Terrinha P, Duarte J, Roque C, Ranero C, Zitellini N (2017) Micro-seismicity in the Gulf of Cadiz. Is there a link between micro-seismicity, high magnitude earthquakes and active faults? Tectonophysics 717:226-241. https://doi.org/10.1016/j.tecto.2017.07.026 (ISSN 0040-1951)

Silwal V, Tape C (2016) Seismic moment tensors and estimated uncertainties in southern Alaska. J Geophys Res 121(4):2772-2797. https://doi. org/10.1002/2015JB012588

Stich D, Martin R, Morales J (2010) Moment tensor inversion for IberiaMaghreb earthquakes 2005-2008. Tectonophysics 483:390-398. https:// doi.org/10.1016/j.tecto.2009.11.006

Storchak DA, Schweitzer J, Bormann P (2003) The IASPEI standard seismic phase list. Seism Res Let 74:761-772

Storchak DA, Schweitzer J, Bormann P (2011) Seismic phase names: IASPEI standard. In: Gupta H (ed) Encyclopedia of solid earth geophysics. Springer, Dordrecht, pp 1162-1173

Storchak DA, Di Giacomo D, Bondár I, Engdahl ER, Harris J, Lee WHK, Villaseñor A, Bormann P (2013) Public Release of the ISC-GEM Global Instrumental Earthquake Catalogue (1900-2009). Seism Res Let 84(5):810-815. https:// doi.org/10.1785/0220130034

Storchak DA, Kanao M, Delahaye E, Harris J (2015) Long-term accumulation and improvements in seismic event data for the polar regions by the International Seismological Centre. Polar Sci 9(1):5-16. https://doi. org/10.1016/j.polar.2014.08.002

Storchak DA, Harris J, Brown L, Lieser K, Shumba B, Verney R, Di Giacomo D, Korger EIM (2017) Rebuild of the Bulletin of the International Seismological Centre (ISC), part 1: 1964-1979. Geosci Lett 4:32. https://doi. org/10.1186/s40562-017-0098-z

Stork AL, Stuart GW, Henderson CM, Keir D, Hammond JOS (2013) Uppermost mantle $(\mathrm{Pn})$ velocity model for the Afar region, Ethiopia: an insight into rifting processes. Geophys J Int 193:321-328. https://doi.org/10.1093/gji/ ggs 106

Sutherland FH, Vernon FL, Orcutt JA, Collins JA, Stephen RA (2004) Results from OSNPE: improved teleseismic earthquake detection at the seafloor. Bull Seism Soc Am 94:1868-1878. https://doi.org/10.1785/012003088

Syracuse EM, Abers GA, Fischer K, MacKenzie L, Rychert C, Protti M, Gonzalez V, Strauch W (2008) Seismictomography and earthquake locations in the Nicaraguan and Costa Rican upper mantle. Geophys Geosyst Geochem. https://doi.org/10.1029/2008GC001963

Syracuse EM, Holt RA, Savage MK, Johnson JH, Thurber CH, Unglert K, Allan KN, Karaliyadda S, Henderson M (2012) Temporal and spatial evolution of hypocentres and anisotropy from the Darfield aftershock sequence: Implications for fault geometry and age, N.Z. J Geol Geophys 55:287-293. https://doi.org/10.1080/00288306.2012.690766

Syracuse EM, Thurber C, Rawles C, Savage M, Bannister S (2013) High-resolution relocation of aftershocks of the Mw 7.1 Darfield, New Zealand, earthquake and implications for fault activity. J Geophys Res Solid Earth 118:4184-4195. https://doi.org/10.1002/jgrb.50301

Tape C, Silwal V, Ji C, Keyson L, West ME, Ruppert N (2015) Transtensional tectonics of the Minto Flats Fault Zone and Nenana Basin Central Alaska. Bull Seism Soc Am 105(4):2081-2100. https://doi.org/10.1785/0120150055

Taymaz T, Jackson JA, Westaway R (1990) Earthquake mechanisms in the Hellenic Trench near Crete. Geophys J Int 102:695-731

Vales D, Dias NA, Rio I, Matias L, Silveira G, Madeira J, Weber M, Carrilho F, Haberland C (2014) Intraplate seismicity across the Cape Verde swell: a contribution from a temporary seismic network. Tectonophysics 636:325-337. https://doi.org/10.1016/j.tecto.2014.09.014

Vanĕk J, Zátopek A, Kárnik V, Kondorskaya NV, Riznichenko YV, Savarenski EF, Solov'ev SL, Shebalin NV (1962) Standardization of magnitude scales. Izvestiya Akademii Nauk SSSR Seriya Geofisičeskaya 2:153-157 (with English translation)

Velasco AA, Gee VL, Rowe C, Grujic D, Hollister LS, Hernandez D, Miller KC, Tobgay T, Fort M, Harder S (2007) Using small, temporary seismic networks for investigating tectonic deformation: brittle deformation and evidence for strike-slip faulting in Bhutan. Seism Res Let 78(4):446-453. https://doi. org/10.1785/gssrl.78.4.446

Wagner LS, Beck S, Zandt G (2005) Upper mantle structure in the south central Chilean subduction zone (30 to $\left.36^{\circ} \mathrm{S}\right)$. J Geophys Res. https://doi. org/10.1029/2004JB003238

Wang X, Chen Q, Li J, Wei S (2016) Seismic Sensor misorientation measurement using p-wave particle motion: an application to the NECsaids array. Seism Res Lett 87(4):901-911. https://doi.org/10.1785/0220160005

Weber Z (2016) Source parameters for the 2013-2015 earthquake sequence in Nógrád county Hungary. J Seism. https://doi.org/10.1007/s109500169 5766

Wessel P, Luis JF, Uieda L, Scharroo R, Wobbe F, Smith WHF, Tian D (2019) The Generic Mapping Tools version 6. Geochem Geophys Geosyst 20:5556-5564. https://doi.org/10.1029/2019GC008515

Weston J, Engdahl ER, Harris J, Di Giacomo D, Storchack DA (2018) ISC-EHB: Reconstruction of a robust earthquake dataset. Geophys J Int 214(1):474484. https://doi.org/10.1093/gji/ggy155

Willemann RJ, Storchak DA (2001) Data collection at the International Seismological Centre. Seism Res Let 72:440-453

Young JB, Presgrave BW, Aichele H, Wiens DA, Flinn EA (1996) The FlinnEngdahl regionalisation scheme: the 1995 revision. Phys Earth Planet Int 96:223-297

\section{Publisher's Note}

Springer Nature remains neutral with regard to jurisdictional claims in published maps and institutional affiliations.

\section{Submit your manuscript to a SpringerOpen ${ }^{\circ}$ journal and benefit from:}

- Convenient online submission

- Rigorous peer review

- Open access: articles freely available online

- High visibility within the field

- Retaining the copyright to your article

Submit your next manuscript at springeropen.com 